ISSN 2313-4321

www.mdpi.com/journal/recycling

Review

\title{
Current Developments and Challenges in the Recycling of Key Components of (Hybrid) Electric Vehicles
}

\author{
Tobias Elwert ${ }^{1, *}$, Daniel Goldmann ${ }^{1}$, Felix Römer ${ }^{1}$, Matthias Buchert ${ }^{2}$, Cornelia Merz ${ }^{2}$, \\ Doris Schueler ${ }^{2}$ and Juergen Sutter ${ }^{2}$
}

1 Department of Mineral and Waste Processing, Institute of Mineral and Waste Processing, Waste Disposal and Geomechanics, Clausthal University of Technology, Walther-Nernst-Strasse 9, Clausthal-Zellerfeld 38678, Germany; E-Mails: daniel.goldmann@tu-clausthal.de (D.G.); felix.roemer@tu-clausthal.de (F.R.)

2 Division Infrastructure \& Enterprises, Oeko-Institut e. V.- Institute for Applied Ecology, Rheinstrasse 95, Darmstadt 64295, Germany; E-Mails: m.buchert@oeko.de (M.B.); c.merz@oeko.de (C.M.); d.schueler@oeko.de (D.S.); j.sutter@oeko.de (J.S.)

* Author to whom correspondence should be addressed; E-Mail: tobias.elwert@tu-clausthal.de; Tel.: +49-532-372-2119; Fax: +49-532-372-2353.

Academic Editor: Michele Rosano

Received: 16 September 2015 / Accepted: 15 October 2015 / Published: 22 October 2015

\begin{abstract}
The introduction of electromobility causes major challenges as new components and materials enter vehicle recycling. This paper discusses the current developments in the recycling of traction batteries, electric motors, and power electronics, which constitute the key components of (hybrid) electric vehicles. Both technical and ecological aspects are addressed. Beside base metals, all components contain metals that are considered critical by the EU (European Union), e.g., rare earth elements, cobalt, antimony, and palladium. As electromobility is a new trend, no recycling routes have been established at an industrial scale for these components. The implementation is complicated by small return flows and a great variety of vehicle concepts as well as components. Furthermore, drastic changes regarding design and material compositions can be expected over the next decades. Due to hazards and high weights, there is a strong research emphasis on battery recycling. Most pilot-scale or semi-industrial processes focus on the recovery of cobalt, nickel, and copper due to their high value. Electric motors and power electronics can be fed into established recycling routes if they are extracted from the vehicle before shredding.
\end{abstract}


However, these processes are not capable of recovering some minor metals such as rare earth elements and antimony.

Keywords: electromobility; recycling; hybrid electric vehicles; electric vehicles; traction batteries; electric motors; power electronics; critical metals; life cycle assessment

\section{Introduction}

The environmental impact of a petroleum-based infrastructure, the finite nature of fossil fuel supply as well as advances in battery technology, fuel cells, electric motors, and power electronics have led to an increasing interest in hybrid (HEV), plug-in hybrid (PHEV), fuel cell (FCEV), and electric vehicles (EV) in recent years. Although there is a lively debate about competing technologies, the necessary infrastructure, time scales for market penetration, environmental impact, safety aspects, etc., most experts agree that these vehicles will play a significant role in our future mobility.

As HEVs, FCEVs and EVs introduce new components, the spread of electromobility will lead to major changes in vehicle recycling practices within the upcoming years. These components are mainly traction batteries, electric drive motors, power electronics, and in the case of FCEVs, fuel cells. Additionally, new components such as electric heaters as well as new vehicle designs can be expected. For example, the use of wheel hub motors might lead to drastically changed designs. Furthermore, the general trend of lightweight construction will result in new material compositions [1,2].

The introduction of these components is an enormous challenge, not only for vehicle recyclers, but also for subsequent recycling industries such as battery recyclers, carmakers and the associated supplier industry, as well as politics and legislation. Challenges derive, among others, from a still-to-be-established recycling infrastructure, complex assemblies and material composites, low concentrations of some critical metals, comparatively low volumes with sometimes highly variable chemical compositions, and, in the case of batteries, from high energy contents [3-6].

Nevertheless, in the case of a mass implementation of $(\mathrm{H}) \mathrm{EVs}$ and FCEVs, sophisticated recycling technologies addressing these developments are of high importance, not only for environmental and safety reasons, but also to secure the mid- and long-term supply of the required raw materials. Examples are lithium, nickel and cobalt in lithium ion batteries (LIB), neodymium and dysprosium in electric motors and precious metals, tantalum and tin in power electronics [7-9].

Therefore, in recent years, a considerable number of national and international efforts have been initiated by the private and public sectors in $(\mathrm{H}) \mathrm{EV}$ recycling. The aim of this article is to present a general survey of the current developments and challenges in the recycling of traction batteries, electric drive motors and power electronics. The article focuses on (potential) industrial solutions covering the full recycling chain from removal of the target components from end-of-life vehicles to raw material production. Fuel cells are not covered due to their expected relatively low quantity in comparison to the other components [10]. 


\section{Background}

In this chapter, the assembly of traction batteries, electric drive motors and power electronics is described, as well as is ongoing research, which might be found in next generation vehicles. Additionally, raw material supply, legal aspects and today's vehicle recycling practice are briefly discussed.

\subsection{Key Components of $(H) E V S$}

\subsubsection{Traction Batteries}

Traction batteries are those used for the propulsion of any type of electric vehicle. Traction batteries installed in today's (H)EVs are almost exclusively either of the nickel-metal hydride (NiMH) or LIB type. Due to their higher capacities, LIBs increasingly replace NiMH batteries. Nevertheless, they will stay in the HEV market for a while [3].

Depending on their use in HEVs, PHEVs or EVs, traction batteries exist in a wide range of designs, sizes, weights, capacities, power-to-energy ratios, and possible cycles, and they operate over different amounts of the battery state of charge (SOC) as exemplarily shown in Figure 1.

\begin{tabular}{|c|c|c|c|c|c|c|c|}
\hline OEM Model & BMW i3 & VWE-UP & Nissan Leaf & Mitsubishi i-MiEV & Tesla Model S & Opel Ampera & Ford Mondeo \\
\hline $\begin{array}{l}\text { Position of battery } \\
\text { in the car }\end{array}$ & & & & & & & \\
\hline Type of drive & EV & EV & EV & EV & EV & EREV & HEV \\
\hline Manufacturer & Samsung SDI & Samsung SDI & AESC & GS Yuasa & Panasonic/Sanyo & LG Chem & Panasonic/Sanyo \\
\hline Cell shape & prismatic & prismatic & pouch & prismatic & cylindrical & pouch & $\begin{array}{l}\text { prismatic } \\
\end{array}$ \\
\hline Capacity [kWh] & 18,8 & 18,7 & 24 & 16 & $16,2-17,7$ & 16 & 7,6 \\
\hline Nominal voltage [M] & 360 & 374 & 360 & 330 & 402 & 360 & \\
\hline Number of cells & 96 & 204 & 192 & 88 & 7104 & 288 & 76 \\
\hline $\begin{array}{l}\text { Number of modules } \\
\mathrm{x} \text { Cells }\end{array}$ & $8 \times 12$ & $17 \times 12$ & $48 \times 4$ & $\begin{array}{r}10 \times 8 \\
2 \times 4 \\
\end{array}$ & $16 \times 444$ & $\begin{array}{l}7 \times 36 \\
2 \times 18 \\
\end{array}$ & $2 \times 38$ \\
\hline $\begin{array}{l}\text { Module dimensions } \\
(\mathrm{I} \times \mathrm{w} \times \mathrm{h} \text { in }[\mathrm{mm}])\end{array}$ & - & $1726 \times 1132 \times 303$ & $303 \times 223 \times 35$ & $\begin{array}{l}1.350 \times 194 \times 116 \\
2175 \times 194 \times 116 \\
\end{array}$ & $178 \times 102 \times 152$ & $\begin{array}{l}\text { 1. } 230 \times 220 \times 25 \\
\text { 2. } 140 \times 220 \times 25 \\
\end{array}$ & - \\
\hline M odule weigth [kg] & - & 10,5 & $\mathbf{3 , 8}$ & $\begin{array}{r}1.15 \\
2.7,5 \\
\end{array}$ & - & $\begin{array}{c}1.19 \\
2.9\end{array}$ & - \\
\hline \begin{tabular}{|l|} 
Arrangement of \\
modules (top view)
\end{tabular} & 䙵 & $\square \square \square$ & $:$ & 严 & & - & \\
\hline \begin{tabular}{|l|} 
Arrangement of \\
modules (side view)
\end{tabular} & & $\bar{\square}-\bar{\square}$ & 吾=三 & 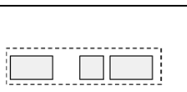 & 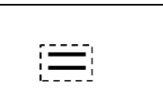 & $\square \square$ & \\
\hline Ele ctric range [km] & 190 & 160 & 175 & 160 & 400 & $40-80$ & 34 \\
\hline Pack weigth $[\mathrm{kg}]$ & 230 & 230 & 300 & 200 & 600 & 198 & 240 \\
\hline
\end{tabular}

Figure 1. Examples of current $(\mathrm{H}) \mathrm{EVs}$ and their batteries. (OEM: original equipment manufacturer, EREV: extended-range electric vehicle) Reproduced with permission from Natkunarajhah, N., Advanced Automotive and Stationary Battery Conference: Proceedings; published by AABC Europe, 2015 [11].

For instance, HEVs such as the Toyota Prius require a power battery to generate the acceleration and accept the power created through regenerative braking. While high power is required, very low energy is needed in these batteries. Typically, an HEV battery will have a power-to-energy ratio of about 20:1 or more and will operate over a relatively small amount of the battery SOC, which enables up to 300,000 cycles or more. In contrast, EVs require much larger energy batteries. The power-to-energy ratio of an EV is typically in the range of $4: 1$ or less. The battery operates at around $90 \%$ SOC, which allows for 3000-4000 cycles [3,11,12]. 
Traction batteries generally include four main components which are the battery cells, the battery management system (BMS) and electronics, the thermal management system and mechanical structure and/or modules $[3,13]$.

\section{Nickel-Metal Hydride Cells}

The nickel-metal hydride battery is a rechargeable battery which uses nickel oxyhydroxide $(\mathrm{NiO}(\mathrm{OH}))$ as the cathode material and a hydrogen-absorbing alloy $(\mathrm{M})$ as the anode material. The electrode reactions occurring are (discharge left to right, Equations (1) and (2)):

$$
\begin{gathered}
\text { Anode: } \mathrm{H}_{2} \mathrm{O}+\mathrm{M}+\mathrm{e}^{-} \leftrightarrow \mathrm{OH}^{-}+\mathrm{MH} \\
\text { Cathode: } \mathrm{Ni}(\mathrm{OH})_{2}+\mathrm{OH}^{-} \leftrightarrow \mathrm{NiO}(\mathrm{OH})+\mathrm{H}_{2} \mathrm{O}+e^{-}
\end{gathered}
$$

The most common alloy is an $\mathrm{AB}_{5}$ compound, in which $\mathrm{A}$ stands for a rare earth element (REE) mixture of lanthanum, cerium, neodymium, praseodymium (called mischmetal) and B stands for nickel, cobalt, manganese, and/or aluminum. The electrolyte is usually $20 \% \mathrm{KOH}$. For separation, hydrophilic polyolefin nonwovens are used. Due to their relatively low specific energy of $80 \mathrm{Wh} / \mathrm{kg}$, NiMH batteries are mainly used in HEVs, whereas for PHEVs and EVs LIBs are preferred [14].

\section{Lithium Ion Cells}

The term LIB refers to a group of secondary batteries, which have quite different properties regarding specific energy, specific power, durability, costs, boost charge ability and safety. The properties mainly depend on the employed electrode materials. All these batteries have in common that lithium ions move from the negative electrode to the positive during discharge and back when charging. The electrode reactions occurring in lithium cobalt oxide/graphite-type cells, which were the first commercially available LIBs, are (discharge left to right, Equations (3) and (4)) [4]:

$$
\begin{gathered}
\text { Anode: } \mathrm{LiC}_{6} \leftrightarrow \mathrm{Li}^{+}+\mathrm{e}^{-}+6 \mathrm{C} \\
\text { Cathode: } 2 \mathrm{Li}_{0.5} \mathrm{CoO}_{2}+\mathrm{Li}^{+}+e^{-} \leftrightarrow 2 \mathrm{LiCoO}_{2}
\end{gathered}
$$

Cathode Materials

LIBs use lithium transition metal compound powders coated on aluminum foil as active cathode materials which can de-intercalate lithium ions during charging from their crystal structure (Equation (4)). These materials are classified according to their crystal structure into three main types: layered oxides, spinels and phosphates.

Layered oxides with the chemical formula $\mathrm{LiMO}_{2}$, where $\mathrm{M}=\mathrm{Co}$ and/or $\mathrm{Ni}$ and/or $\mathrm{Mn}$ (and/or $\mathrm{Al}$ ), are the most investigated system for cathode materials. From the variety of possible compounds, only one end member, $\mathrm{LiCoO}_{2}$ (LCO), and two tertiary phases, $\mathrm{LiNi}{ }_{0.8} \mathrm{Co}_{0.15} \mathrm{Al}_{0.05} \mathrm{O}_{2}(\mathrm{NCA})$ and $\mathrm{LiNi}_{0.33} \mathrm{Mn}_{0.33} \mathrm{Co}_{0.33} \mathrm{O}_{2}$ (NMC), are of commercial importance. Mixed oxides have been developed to balance the advantages and disadvantages of the end members. $\mathrm{LiNiO}_{2}$, for example, shows a high capacity of $200 \mathrm{Ah} / \mathrm{kg}$, but poor cycling capability due to unwanted irreversible chemical reactions during discharge. Partial replacement of $\mathrm{Ni}$ by $\mathrm{Co}$ and $\mathrm{Al}$ leads to better stability and extended cell life. At the moment, layered oxides offer the highest specific energy of all commercial cathode materials (see Table 1). One major disadvantage of 
layered oxides is the possible oxygen formation during charging caused by the instability of the $\mathrm{Li}_{1-\mathrm{x}} \mathrm{MO}_{2}$ structure. The oxygen cannot escape from the cell and reacts violently with the organic electrolyte resulting in fire hazards. Further disadvantages are the toxicity of $\mathrm{Co}$ and $\mathrm{Ni}$ as well as their relatively high prices. Therefore, research aims at further Co reduction.

The second group of cathode materials is spinels ( $\left.\mathrm{LiM}_{2} \mathrm{O}_{4}, \mathrm{M}=\mathrm{Mn}, \mathrm{Ni}\right)$. Only $\mathrm{LiMn}_{2} \mathrm{O}_{4}(\mathrm{LMO})$ is commercially available. The main disadvantage of LMO is its very poor cycling capability. In comparison to layered oxides, LMO is cheaper and non-poisonous.

Table 1. Typical capacities, operating voltages and energies of the described cathode materials [15].

\begin{tabular}{cccc}
\hline Material & Capacity $(\mathbf{A h} / \mathbf{k g})$ & Operating Voltage (V) & Energy Density (Wh/kg) \\
\hline $\mathrm{NCA}\left(\mathrm{LiNi}_{0.8} \mathrm{Co}_{0.15} \mathrm{Al}_{0.05} \mathrm{O}_{2}\right)$ & 200 & 3.7 & 740 \\
$\mathrm{LCO}\left(\mathrm{LiCoO}_{2}\right)$ & 160 & 3.9 & 624 \\
$\mathrm{NMC}\left(\mathrm{LiNi}_{0.33} \mathrm{Mn}_{0.33} \mathrm{Co}_{0.33} \mathrm{O}_{2}\right)$ & 160 & 3.7 & 592 \\
$\mathrm{LMO}\left(\mathrm{LiMn}_{2} \mathrm{O}_{4}\right)$ & 100 & 4.1 & 410 \\
$\mathrm{LFP}\left(\mathrm{LiFePO}_{4}\right)$ & 160 & 3.4 & 544 \\
\hline
\end{tabular}

Of high interest for future applications are materials with high operating voltage $(>4.0 \mathrm{~V})$. Possible candidates, among others, are spinel compounds with the formula $\mathrm{Li}\left(\mathrm{M}_{0.5} \mathrm{Mn}_{1.5}\right) \mathrm{O}_{4}$ with $\mathrm{M}=\mathrm{Ni}, \mathrm{Co}$, $\mathrm{Cr}, \mathrm{Fe}$ and $\mathrm{Cu}$. These components allow operating voltages against $\mathrm{Li} / \mathrm{Li}^{+}$of up to $5.1 \mathrm{~V}$. At the moment the applicability of these materials is restricted by maximum electrolyte stabilities of $\leq 4.3 \mathrm{~V}$.

The last group of cathode materials is phosphates $\left(\mathrm{LiMPO}_{4}, \mathrm{M}=\mathrm{Fe}, \mathrm{Mn}, \mathrm{Co}, \mathrm{Ni}\right)$, of which $\mathrm{LiFePO}_{4}$ (LFP) is commercially available. In comparison to oxides, no oxygen formation can occur in phosphates due to the strong covalent bondages within the phosphate structure. This contributes to the superior cycling capability and safety of LFP. Like LMO, LFP is relatively cheap and non-poisonous. The main disadvantage of LFP is its low electric and Li ion conductivity. Current developments aim at developing phosphates using $\mathrm{Mn}$, Co and Ni instead of Fe. These structures allow higher operating voltages than LFP, but also require new high-voltage electrolytes in the cases of $\mathrm{Ni}$ and $\mathrm{Co}$ [15].

Anode Materials

The majority of LIBs use graphite coated on copper foil as the active anode material, which can reversibly intercalate Li ions (Equation (3)). Few use amorphous carbon or lithium titanate, of which the latter is only suitable for stationary applications due to its low specific energy. Future possible anode materials with higher capacities include composites like $\mathrm{C} / \mathrm{Si}$, Si alloys, and non-Si alloys, such as Sn-based and metallic Li. As most of these developments are still in an early stage, trends are difficult to foresee [16].

\section{Electrolytes and Separators}

Liquid electrolytes for LIBs consist of an organic aprotic solvent, a conducting salt and additives. The solvent is typically a mixture of two to four chemicals to meet the required physical and chemical properties for the respective LIB type. Typically, 20\%-50\% ethylene carbonate is mixed with carbonates such as dimethyl, diethyl and ethylmethyl carbonate or esters such as ethyl acetate and 
methyl butyrate. Today's LIBs nearly exclusively use $\mathrm{LiPF}_{6}$ as the conducting salt. To meet future needs, several new conducting salt concepts are under investigation. Additives are highly specific and, in most cases, confidential [17].

Classic separators for LIBs are polyolefin membranes. Ongoing research aims at the development of separators with better durability and safety, e.g., nonwoven aluminum oxide composites [18].

Battery Management System and Thermal Management

The BMS is responsible for monitoring the performance of the battery and adjusting the system to match the usage and environment. It is itself a quite complex electronic system. Further electronic components of the battery pack include high-voltage switches, contactors and fuses as well as a charger [3].

The thermal management system monitors and regulates the temperature of the battery cells in order to keep them within their optimal operating range, which is key to the long life of the battery pack. Both liquid- and air-based systems exist [3].

Material Compositions of Traction Batteries

Table 2 contains average material compositions of traction batteries for different cell types (NMC, NCA and LFP), which are often considered for (H)EVs. It can be seen that the battery cells account for approximately $60 \%$ of the total battery weight; $40 \%$ are casing, BMS and thermal management [19]. Total weights of traction batteries are in the range of $50 \mathrm{~kg}(\mathrm{HEV})$ to $500 \mathrm{~kg}$ (EV) [11].

Table 2. Average material compositions of traction batteries for different cell types. All values in g/kg. Data adapted from [19].

\begin{tabular}{cccc}
\hline Cell type & NMC & NCA & LFP \\
\hline Total & Battery Cells & & \\
\hline Active cathode material & 630 & 598 & 530 \\
Lithium & 191 & 175 & 173 \\
Cobalt & 14 & 13 & 7.6 \\
Nickel & 39 & 16 & 0 \\
Manganese & 39 & 86 & 0 \\
Aluminum & 36 & 0 & 0 \\
Iron & 0 & 2.5 & 0 \\
Phosphorus & 0 & 0 & 61 \\
Oxygen & 0 & 0 & 34 \\
Cathode foil (aluminum) & 63 & 58 & 70 \\
Electrolyte & 39 & 40 & 34 \\
Separator & 114 & 101 & 85 \\
Active anode material (carbon) & 54 & 50 & 43 \\
Anode foil (copper) & 140 & 131 & 111 \\
Cell casing (aluminum) & 66 & 70 & 60 \\
Others & 21 & 20 & 17 \\
Total & 6 & 10 & 8.5 \\
Wiring & 370 & 402 & 470 \\
Copper & 21 & 50 & 64 \\
& 13 & 30 & 38 \\
\hline
\end{tabular}


Table 2. Cont.

\begin{tabular}{cccc}
\hline Cell type & NMC & NCA & LFP \\
\hline & Battery Infrastructure & & \\
\hline Aluminum & 1.4 & 10 & 13 \\
Stainless steel & 7 & 10 & 13 \\
Frame \& Casing & 313 & 342 & 395 \\
Plastics & 107 & 81 & 102 \\
Stainless steel & 206 & 261 & 293 \\
Others (including BMS) & 36 & 10 & 11 \\
\hline
\end{tabular}

\subsubsection{Electric Drive Motors}

The electric drive is one of the key elements in all electric vehicles as it converts electrical into mechanical energy. Due to design, operation requirements, application, power train concept and, finally, material supply, a multitude of different electric motors have been developed for electric vehicles $[1,20]$.

The most important concepts for the motorization of electric vehicles are direct current (DC) motors, induction motors (also known as asynchronous motors), synchronous motors and switched reluctance motors, each bearing a series of advantages and disadvantages [21]. Table 3 gives an overview over prominent examples of different drive configurations. Currently, permanent magnet synchronous and induction motors are the most common ones in electric vehicles. While permanent magnet synchronous motors reach very high power densities and efficiencies, induction motors are cheaper and do not require rare earth-based permanent magnets [21,22]. However, due to the limited space in HEVs and the general interest in light-weight construction, permanent magnet motors are the predominant technology applied in (H)EVs.

Table 3. Electric vehicles sold in the US in 2014 (only models with sales numbers above 1000 are listed, $\mathrm{PM}=$ permanent magnet synchronous motor, $\mathrm{IM}=$ induction motor).

\begin{tabular}{cccc}
\hline (H)EV & Sales & Type & Motor Type \\
\hline Nissan LEAF & 30200 & EV & PM [22] \\
Chevrolet Volt & 18805 & HEV & PM [23] \\
Tesla Model S * & 17300 & EV & IM [24] \\
Toyota Prius PHV & 13264 & HEV & PM [25] \\
Ford Fusion Energi & 11550 & HEV & PM [26] \\
Ford C-Max Energi & 8433 & HEV & PM [26] \\
BMW i3 ** & 6092 & EV/HEV & PM [24] \\
smart ED & 2594 & EV & PM [22] \\
Ford Focus Electric & 1964 & EV & PM [25] \\
Fiat 500e * & 1793 & EV & IM [22] \\
Cadillac ELR & 1310 & HEV & PM [23] \\
Toyota RAV4 EV & 1184 & EV & IM [24] \\
Chevrolet Spark EV & 1145 & EV & PM [27] \\
Total & 119710 & & \\
Worldwide & 320713 & & \\
\hline
\end{tabular}

Sales Numbers according to [28], * Estimated number, ** starting from May 2014. 
Regarding the material composition, modern electric motors mainly consist of cast iron, steel, aluminum, copper and, in case of magnet synchronous motors, $\mathrm{NdFeB}$ magnets. As permanent magnet motors are the most common propulsion types in electric vehicles, two typical material compositions of magnet synchronous motors are shown for their application in EVs and HEVs in Table 4 [6].

$\mathrm{NdFeB}$ magnets contain about $30 \%$ of REE, mainly neodymium and dysprosium with minor amounts of praseodymium and terbium. Magnets applied in synchronous motors often consist of up to $10 \%$ dysprosium, which improves coercivity and, therefore, temperature tolerance $[29,30]$.

Regarding the trends in motor design for electric vehicles, different competing tendencies can be identified. On one hand, many producers and scientists aim at reducing the REE dependency. One major trend for $\mathrm{NdFeB}$ magnets is the reduction of dysprosium due to its high price (458 US\$ $/ \mathrm{kg}$, neodymium 84 US\$/kg, average prices June 2014-May 2015, min. 99\%, Free on Board (FOB) China [31]) and supply criticality (see Chapter 2.2) [30]. Furthermore, research and development currently works on the reduction of magnet usage in general, the development of new magnet materials and the improvement of magnet-free motors [24,32-37]. On the other hand, new drive train concepts such as in-wheel motors [38,39], vehicle size reduction, and lightweight construction [40] implicate a broader usage of permanent magnet motors because of their high power densities. For this reason, the development of electrical motorization and the future material composition of electric motor scrap from vehicles is difficult to predict accurately.

Table 4. Typical material compositions of permanent magnet synchronous motors. Data adapted from [6].

\begin{tabular}{ccc}
\hline \multirow{2}{*}{ Material } & PM-Motor in EVs; 80 kW & PM-Motor in HEVs; 20 kW \\
\cline { 2 - 3 } & $\mathbf{( k g )}$ & $\mathbf{( k g )}$ \\
\hline Steel & 34.8 & 23.1 \\
Aluminum & 14.1 & 4.7 \\
Magnets & 2.1 & 1.4 \\
Cast Iron & 3.0 & 0 \\
Copper & 8.5 & 6.4 \\
Polymers & 0 & 0.6 \\
Elastomers & 0 & 0.1 \\
Liquids & 0 & 7.7 \\
In Total & 62.5 & 44.0 \\
\hline
\end{tabular}

\subsubsection{Power Electronics}

The power electronics has the task to adapt the electrical energy from the battery to the requirements of the electric machine. It is a key component of all EVs and HEVs and has a high impact on the overall energy efficiency of the drive train. In order to optimize the energy flow in the vehicle, the power electronics has several functions with further sub-components [41]:

- The inverter converts the direct current of the battery to alternating current (AC) for operation of the electric motor.

- The DC voltage converter supplies the on-board electrical system (low volt auxiliary consumers) with low voltages. 
- Some vehicle concepts also foresee an additional DC converter which converts the battery voltage to a higher voltage before converting it to $\mathrm{AC}$ for the electric motor by a downstream inverter.

- The power electronics also comprises printed circuit boards with control electronics.

- Additionally, an onboard-charger with an AC-DC converter is used in BEV and PHEV as a link between the external grid and battery.

Most current EVs and HEVs integrate the inverter for the electric machine, the DC voltage converter for the on-board electric system, and the control electronics in one module, the so-called power electronics module. This module usually has an overall weight of approximately $10 \mathrm{~kg}$ and an aluminum cast casing. The core element is the inverter which is equipped with power semiconductor modules. These semiconductors are a very efficient and compact technology for power conversion compared to the previously used electromechanical transformers. Our own dismantling investigations of typical power electronics provided the following components:

- Casing and cooling (mainly aluminum) (50\%-60\%)

- Power semiconductor module board (1.5\%-3\%)

- Several printed circuit boards with small electronic components $(5 \%-7 \%)$

- Large capacitors (mainly film capacitors) (7\%-20\%)

- Inductors $(5 \%-10 \%)$

- Mounting material, wiring, others $(15 \%-25 \%)$

The boards with electronic components (power electronics and control electronics) contribute to less than $10 \%$ of the total weight and contain mainly medium ( $\mathrm{Au}>100 \mathrm{ppm})$ to high-grade $(\mathrm{Au}>300 \mathrm{ppm})$ printed circuit boards. Table 5 shows the average concentrations of identified valuable metals in these boards for a selected sample.

Table 5. Average valuable metals share in printed circuits boards of a selected power electronics module.

\begin{tabular}{cc}
\hline Element & Average Content \\
\hline $\mathrm{Cu}$ & $33.1 \%$ \\
$\mathrm{Au}$ & $313 \mathrm{ppm}$ \\
$\mathrm{Ag}$ & $625 \mathrm{ppm}$ \\
$\mathrm{Pd}$ & $31 \mathrm{ppm}$ \\
$\mathrm{Ta}$ & $0.29 \%$ \\
$\mathrm{Sb}$ & $157 \mathrm{ppm}$ \\
$\mathrm{Sn}$ & $0.93 \%$ \\
\hline
\end{tabular}

The foregoing paragraphs described the state-of-the-art in power electronics. However, many research and development (R\&D) activities suggest the use of new materials and designs within the next decade. The main R\&D targets are an energy efficiency increase and the availability of lighter and more compact power electronics modules. One approach towards this goal is the application of new semiconductor materials such as silicon carbide $(\mathrm{SiC})$ or gallium nitride $(\mathrm{GaN})$ instead of the currently used silicon. Both $\mathrm{SiC}$ and $\mathrm{GaN}$ enable the operation of chips with higher frequencies and at higher temperatures. This allows the miniaturization of power electronics modules (less waste heat, less cooling, smaller capacitors, smaller inductors). However, this development requires not only a reliable 
new chip generation but also a higher temperature resistance in peripheral components up to $120{ }^{\circ} \mathrm{C}$ instead of the current $80{ }^{\circ} \mathrm{C}$. Today's solder points and capacitors do not withstand these higher temperatures. Following this, R\&D looks for better temperature resistance of alternative capacitors, e.g., ceramic capacitors, and investigates efficient film capacitor cooling systems. R\&D is further conducted on new connection, mounting, cooling and casing technologies. Trends are sintering instead of soldering and replacement of wire bonders, e.g., by silver foils $[42,43]$.

$\mathrm{SiC}$ power modules have already been used in industrial applications for a few years. In automobiles, onboard chargers and information technologies (IT) will probably be the first applications. The use in power electronic modules in EVs is expected to start in five to 15 years, when the chip technology is further advanced and the peripheral components are adapted to higher temperatures. Probably, SiC will pave the way for the more recent $\mathrm{GaN}$ technology which might be available at lower costs in the future but still needs R\&D, testing and up-scaling. The amount of GaN will be very small (approximately $300 \mathrm{mg}$ per power electronics module) since GaN is deposited as a 5-10 $\mu \mathrm{m}$ layer on a silicon substrate. Despite these changes, the currently used materials will also be part of future power electronics modules. Optimistic predictions for an overall weight reduction expect a mass reduction of up to $50 \%$. However, an opposite effect might arise from the future demand for increasingly powerful EV motors [42,44,45].

The principal power electronics design with one central module is expected to remain the standard solution at least within the next decade. However, R\&D is already conducted on different decentralization levels. For example, researchers are developing a motor prototype with integrated power electronics [46]. This design might offer advantages in vehicle control, energy efficiency and weight reduction and might lead to reduced production costs in the long term. However, this approach shows significant technological challenges regarding mechanical reliability, temperature resistance and the required sophisticated integrated production technology [42].

\subsection{Criticality of Raw Materials}

All components described above contain elements which are currently defined as critical raw materials by the European Commission due to their economic importance and supply risk (Figure 2). These are mainly cobalt (NiMH and LIBs), light REEs (NiMH batteries and NdFeB magnets), dysprosium of the heavy REEs (NdFeB magnets), as well as gallium, antimony and palladium of the platinum group metals, which are or might be used in (future) power electronics [7]. Additionally, growing concerns about the future tin supply have recently been expressed by Elsner et al. [47]. Tin is considered near critical by the EU criticality assessment.

The cobalt market is relatively small $(112,000 \mathrm{t}$ in 2014) and characterized by high annual growth rates. In 2014, 50\% of the mine production originated from the Democratic Republic of the Congo. The other $50 \%$ is relatively evenly distributed over more than 10 countries. Although no cobalt shortages are expected within the next years, cobalt is considered critical due to the political instability of the main producer $[7,48,49]$. In $2012,38 \%$ of the cobalt production was already used in battery chemicals [50]. At the moment, complete cobalt substitution in cathode materials of LIBs is difficult due to the superior properties of layered oxides [15]. 


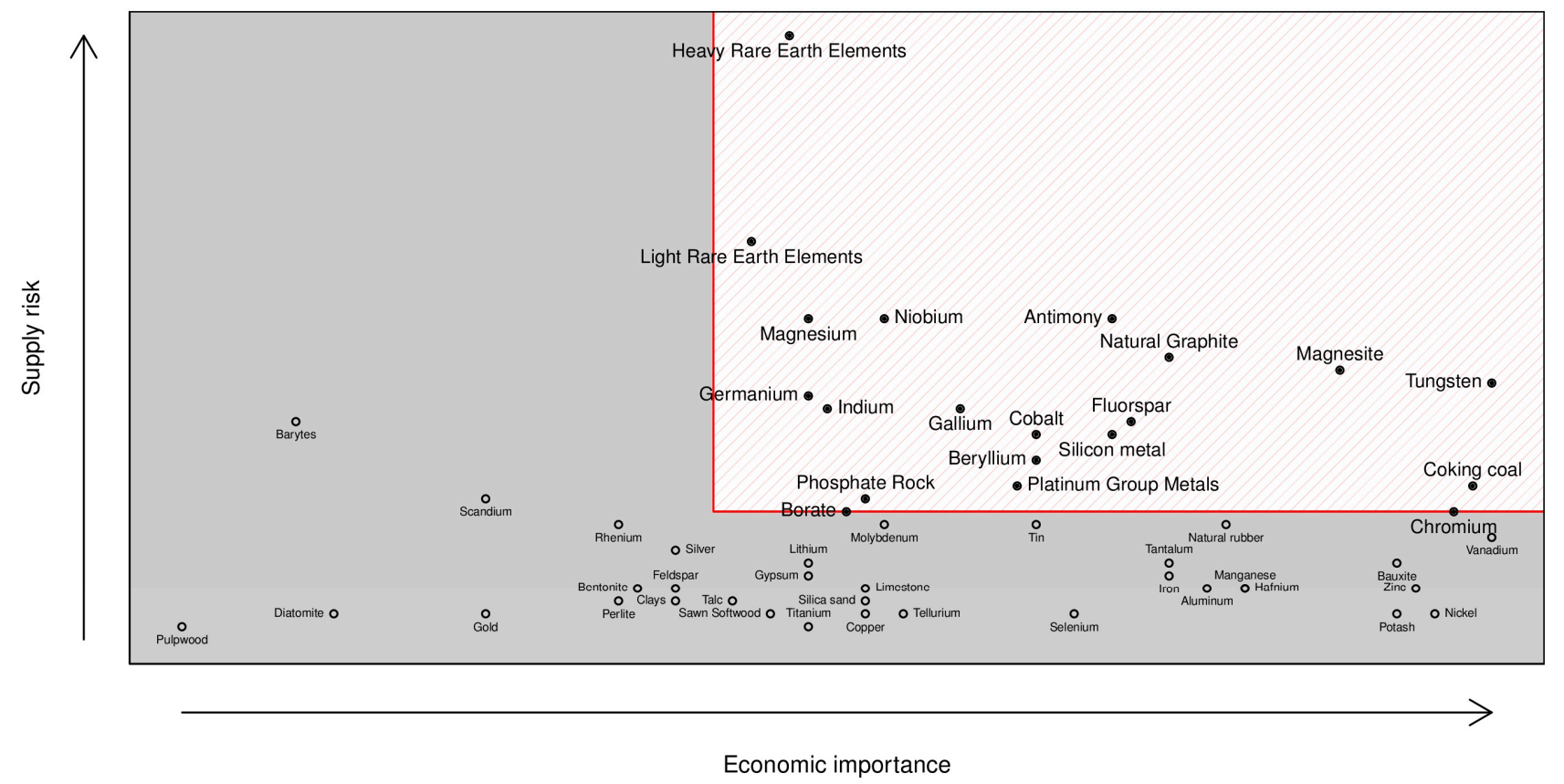

Figure 2. Results of the 2013 EU criticality assessment; the critical raw materials are highlighted in the red shaded (upper right) criticality zone of the graph [7].

Although REEs are quite abundant elements which occur in a variety of deposits around the world, China has virtually become a monopolist for REEs with the help of a state-run raw materials policy [49]. The impacts of this policy are increased prices and supply risks for REEs outside China. Currently, a slight easing of the market for light REEs can be observed due to the (re)opening of mines outside China, which contain mainly light REEs. The heavy REE market is still almost fully controlled by China. With regard to $(\mathrm{H}) \mathrm{EV}$, REEs are of moderate importance as REE demand for NiMH batteries is declining and alternative technologies exist for REE containing synchronous motors. However, if synchronous motors will be the predominant technology in future (H)EVs, the mass implementation of electromobility will lead to a strong increase in the demand for neodymium and dysprosium $[6,9]$.

The impact of power electronics for $(\mathrm{H}) \mathrm{EV}$ s on the demand for electronic metals can generally be considered as low [9]. A possible major impact on the overall demand was predicted only for gallium by Buchert et al. [9]. In the case of palladium and antimony, supply risks derive mainly from high concentrations of supply. In 2014, 74\% of the extracted $190 \mathrm{t}$ palladium was mined in Russia and South Africa, and $78 \%$ of 160,000 $\mathrm{t}$ antimony in China [48]. Of the annual tin production of 296,000 $\mathrm{t}$ (2014), 52\% was used in solders. Due to an expected decline in Peruvian and Indonesian tin productions caused mainly by the depletion of some deposits, Elsner et al. forecast a gap between supply and demand from 2018 on. In the short and medium term, this gap will probably not be compensated by new mining projects $[47,48]$.

Although currently not considered critical by the EU criticality assessment and most studies, lithium should be monitored closely as there is no substitute for lithium used in batteries. Furthermore, the known reserves are concentrated in few countries [7,8]. 


\subsection{Legal Framework in the European Union}

In Europe, (H)EV recycling is primarily regulated by Directive 2000/53/EC on end-of-life vehicles which covers aspects along the life cycle of a vehicle as well as aspects related to treatment operations. Of particular importance in the context of this article are the current (starting in 2015) minimum reuse, recycling and recovery targets of $85 \%$ (reuse + recycling) and 95\% (reuse + recovery), respectively, as well as the de-pollution of fluids and specific components such as batteries (see Chapter 2.4). For definitions of the terms reuse, recycling and recovery, see Directive 2000/53/EC (article 2) and Directive 75/442/EEC (annex IIB).

The further treatment of batteries is regulated by Directive 2006/66/EC. According to this directive, traction batteries belong to the group of "industrial batteries". Battery recycling processes for industrial LIB and NiMH batteries must meet a minimum recycling efficiency of $50 \%$ by average weight.

\subsection{State-of-the-Art Vehicle Recycling}

Due to the mentioned directive, the vehicle waste system in Europe is comparatively homogeneous, and according to the EU commission, the 2006 recycling goals for ELVs have been met by most member states by 2012 . With a European average of a $84.2 \%$ reuse and recycling rate and a $88.5 \%$ reuse and recovery rate, the European ELV waste system could not yet fulfill the 2015 standards [51]. The following Figure 3 shows the common recycling route of ELVs.

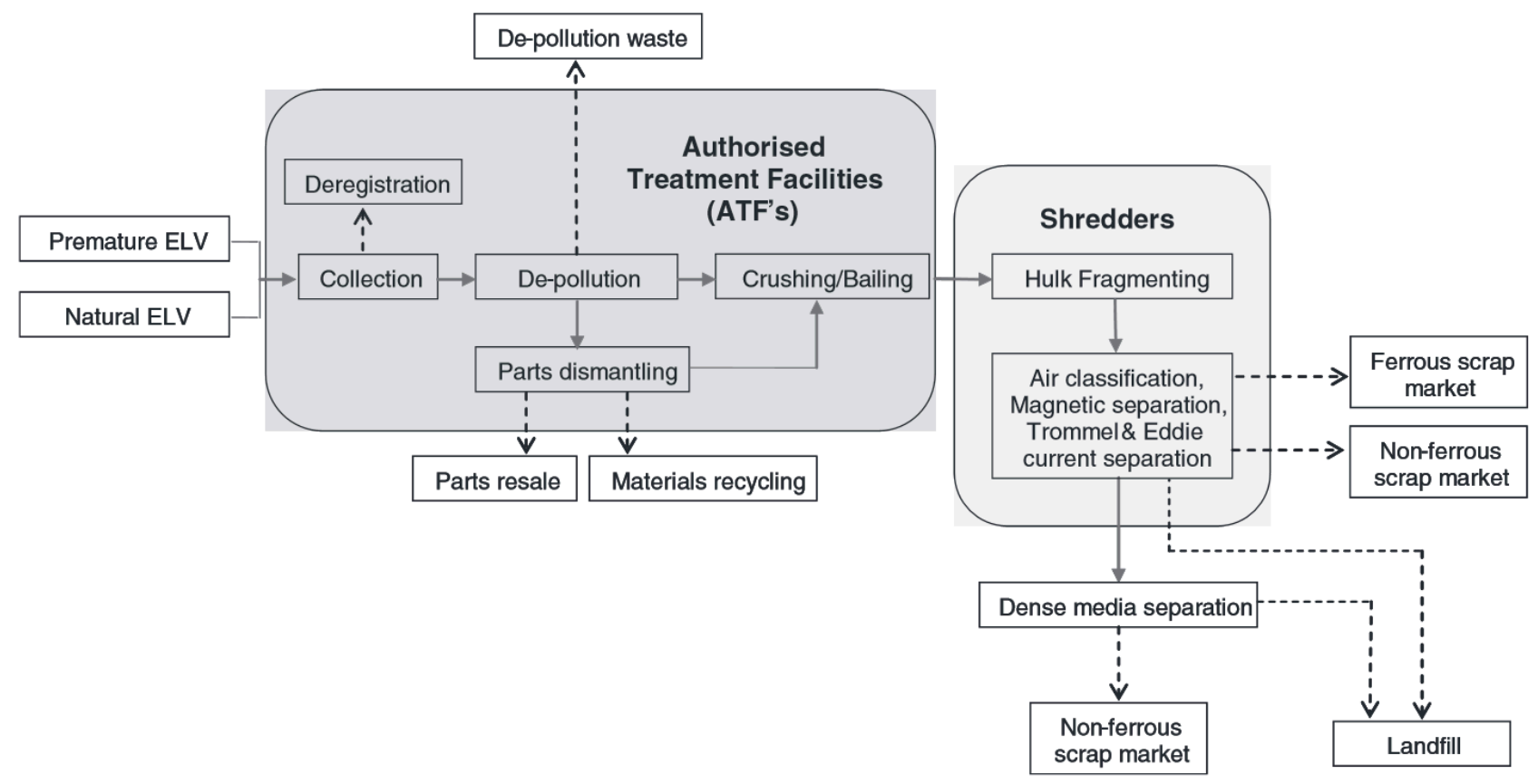

Figure 3. Common recycling route of ELVs [52].

The recycling mainly consists of de-pollution, dismantling, shredding and post-shredding sorting. By law, ELVs can be turned in by the consumer without any costs. Firstly, they are de-polluted in authorized treatment facilities in order to extract potentially hazardous components and toxic materials such as operating liquids, airbags and batteries. Furthermore, specific parts are dismantled either because of their material value (i.e., catalysts), re-use (i.e., engines, tires, electronics) or bad recyclability in the 
following process steps [53-56]. Following the dismantling, the ELVs are usually shredded and processed with magnetic (iron concentrate), eddy-current (mixed non-iron metal concentrate) and density separators (plastic, dust, light materials). For a long time, the auto shredder residue (ASR), mainly light components and metals as well as glass-rich shredder sand, was landfilled. As it constitutes as much as $20 \%$ of the entire mass flow and could only be landfilled as hazardous waste, different approaches had to be developed in order to comply with imposed recycling goals, mitigate environmental risks and minimize landfill costs $[52,57]$. Therefore, different extended dismantling as well as recycling concepts were introduced [53,54,58,59].

Although a recycling system has therewith been installed, strongly varying ASR compositions, losses of partially scarce metals due to dilution and improper treatment, as well as new materials applied i.e., in lightweight design and electric vehicles, pose new challenges for the treatment of ELVs [55,60-64]. Regarding the recycling of more scarce materials, better post-shredding outcomes, and the ecological dimension, great potential lies in a more sophisticated and extensive disassembly and re-use which is currently considered financially infeasible in Europe due to high labor costs and existing but insufficient support by the producers (i.e., design for dismantling) $[55,65,66]$.

\section{Necessary Changes in the Pretreatment of End-of-Life Vehicles through Electromobility}

According to Directive 2000/53/EC on end-of-life vehicles, the removal of batteries is mandatory prior to shredding and post-shredding sorting. Although the removal of electric motors and power electronics is not prescribed by law, it is a prerequisite for a specific treatment of these components to recover minor metals. Furthermore, the ambitious recycling and recovery targets of Directive 2000/53/EC are difficult to achieve without specific treatment of individual components. In the following, the publically available information on the disassembly of traction batteries, electric motors and power electronics is briefly summarized.

\subsection{Disassembly of Traction Batteries}

Due to the high weights and voltages, the disassembly of traction batteries requires specially qualified employees and specific tools. Results from different research projects show that the disassembly of the battery pack can be quite time-consuming as there is often a conflict of interest between the vehicle design with respect to crash safety, center of gravity, space utilization, etc., and the realization of service-friendly installation positions. Additionally, a wide variety of designs exists. Standardization can hardly be expected, but as a recommendation, the projects suggest at least the installation of lifting points (e.g., eyelets, fishplates or mounting threads) on all future battery packs to enable the disassembly by standard lifting tools $[5,67]$.

Prior to transportation and further dismantling, a check of the battery condition is highly recommended as several incidents have demonstrated that damaged traction batteries pose an unpredictable fire risk. Checks should include visual assessment (mechanical damages, signs of heat damage, electrolyte leakage) as well as evaluation of diagnosis data from the BMS (voltage, SOC, temperature sensors, etc.). The development of reliable diagnosis tools is therefore of high interest and part of several research projects $[5,67]$. 


\subsection{Disassembly of Electric Motors}

Within the pretreatment of conventional ELVs, already today, internal combustion engines are usually extracted. Apart from components for reuse, this is due to the applied materials and their high concentration. If these materials enter shredding, they are diluted, polluted or lost, resulting in lower earnings for the recyclers. In principle, this should also hold to be true for electric motors from ELVs, though there is little information regarding the value of specific parts and their disassembly so far. However, the integration of components, new design concepts, and the miniaturization tendency might lead to higher disassembly difficulties and, therefore, costs.

Nevertheless, because motors from electric vehicles contain relatively high concentrations of valuable compounds (copper wiring and $\mathrm{NdFeB}$ magnets) that suffer from poor recycling efficiencies during ASR processing, dismantling will presumably play a major role. Specifically, REEs in permanent magnet motors are lost during ASR processing to the iron fraction and subsequent smelting [68]. Therefore, the magnet carrying parts (the rotors) must be separated during disassembly. The research project "Recycling of components and strategic metals from electric drive motors-MORE" [6] modeled a number of scenarios for the disassembly of permanent magnet motors from ELVs down to the rotor/stator level. They considered German labor costs, decentral/central processing and different permanent magnet motor types and concluded that the disassembly to the magnet-bearing rotor is already profitable today, mainly because of the stators' high copper wire content, even if the REEs are not recycled.

\subsection{Disassembly of Power Electronics}

At the moment, no information is publicly available on the disassembly of power electronics from (H)EVs. However, as today's power electronics are compact units of $10 \mathrm{~kg}$ or more containing high value materials, an economic disassembly should be feasible assuming a service-friendly installation position. Regarding the trends of miniaturization and decentralization, an economic disassembly of power electronics might get harder to achieve in the future due to the lower overall weight and higher disassembly costs.

\section{Selected Recycling Processes for Traction Batteries, Electric Drive Motors and Power Electronics}

\subsection{Traction Batteries}

Due to their high energy content and weight as well as their complex assembly, traction batteries require a much more comprehensive treatment than batteries from portable devices to avoid accidents and to make sure that all components of the battery system are treated in the best possible way in terms of economic and environmental efficiency. Therefore, the first step in recycling is the dismantling of the battery system followed by individual treatment of the obtained materials such as battery cells, electronics, aluminum, steel, plastics, etc. With the exception of battery cells, established recycling processes are available. Therefore, only the relatively new recycling processes for LIB (and partly NiMH) cells are discussed. 


\subsubsection{Dismantling}

As already mentioned, traction batteries are potentially harmful due to the high electrical and chemical energy content. Therefore, safety requirements for dismantling plants are high and qualified personnel is needed. Dismantling cannot be carried out by unskilled workers, who are typically employed for other dismantling tasks in high-wage countries, e.g., in electronic scrap treatment. Necessary safety requirements include, among others, a fire protection concept addressing the specific hazards of LIBs, good ventilation and local suction devices, work safety measures addressing the electrical risks and high weights as well as storage sections for hazardous and non-hazardous battery scrap, and special storage areas for batteries with increased fire hazards, e.g., from cars involved in an accident [5].

Due to the relatively low quantities and the wide range of designs, only manual dismantling is used at the moment. Most dismantling plants have no more than pilot plant character. One of the most advanced dismantling plants is operated by Umicore in Hanau, Germany. As other companies follow similar procedures, only this process is described.

Currently, the dismantling plant has a daily capacity of $10 \mathrm{t}$ and can process batteries up to $1000 \mathrm{~kg}$ and with maximum dimensions of $2.5 \mathrm{~m} \times 1.5 \mathrm{~m} \times 1.0 \mathrm{~m}$. After delivery, the batteries are inspected for damage. If the battery is free of damage, the battery is stored intermediately. If the battery shows signs of damage, special measures have to be taken. Prior to dismantling, the SOC is measured and, if necessary, the battery is discharged by a discharge unit which feeds the energy into the public power grid. After discharging, the casing is opened, followed by dismantling on the component level and further inner dismantling of components (Figure 4). After intermediate storage, the battery cells and other material fractions are shipped for further processing [5].

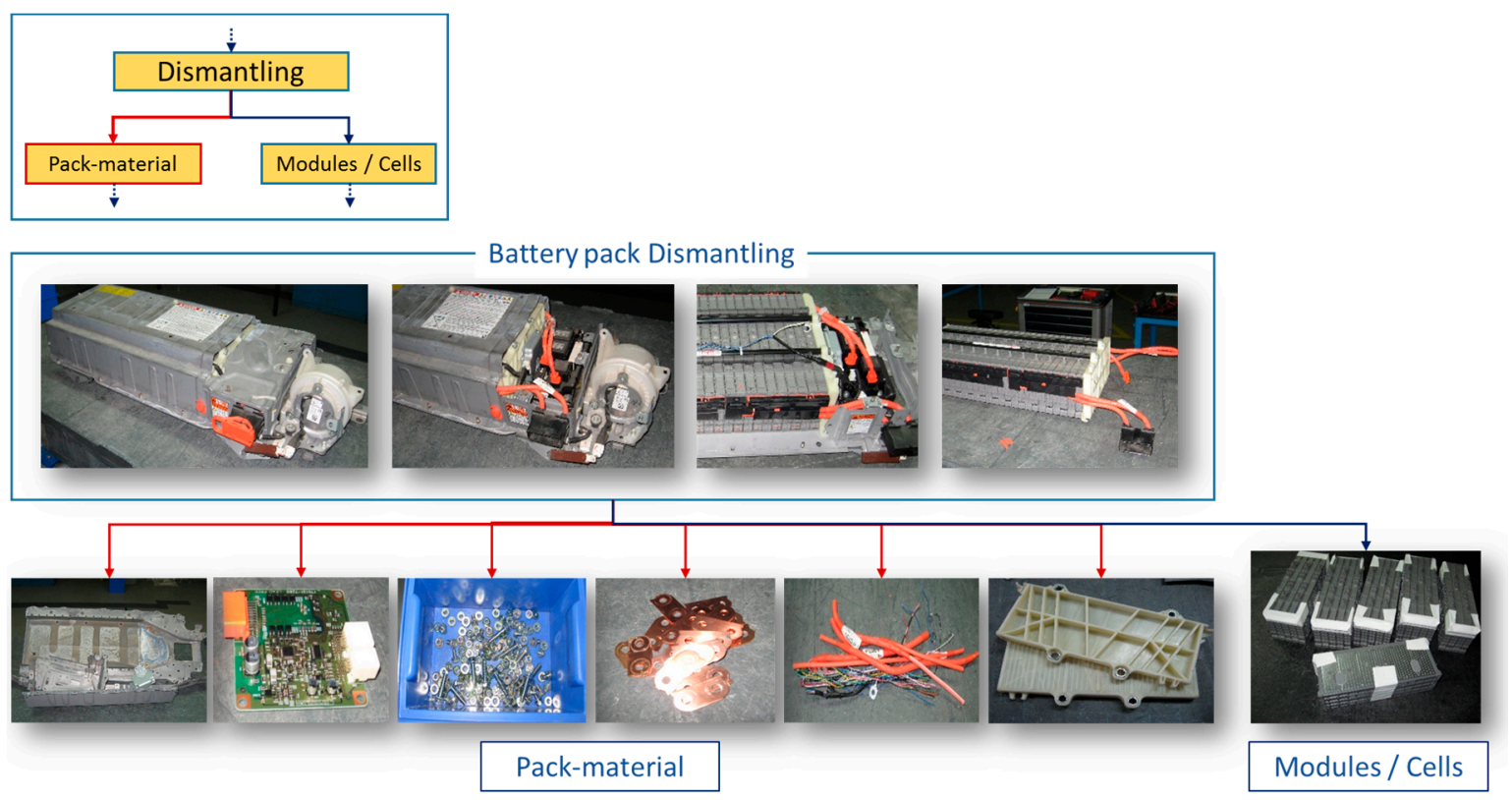

Figure 4. Dismantling of traction batteries at Umicore Battery Recycling, Hanau. With permission of Umicore AG \& Co. KG.

Little information is available on the ease of dismantling of specific battery systems. From the limited information publically available and from oral communication, it can be concluded that, 
due to high concerns about crash safety, many early generation battery systems are quite difficult to dismantle. However, as design for recycling is addressed in several research projects with the participation of car manufacturers, improvements might be expected in future battery generations $[5,67,69,70]$.

\subsubsection{Battery Cell Recycling Processes}

Within the last decade many processes for the recycling of traction batteries have been developed. Recycling plants in Europe have to comply with Directive 2006/66/EC, which requires a minimum recycling quota of $50 \%$. From an economic point of view, the main drivers for recycling are cobalt (31,440 US\$/t, 99.8\%) and nickel (15,914 US\$/t, 99.8\%), followed by copper (6451 US\$/t, grade A, LME) and lithium (6439 US\$/t lithium carbonate, average prices June 2014-May 2015) [31]. Therefore, many processes concentrate on layered oxides and NiMH cells due to their cobalt and nickel content. As lithium ion battery producers aim at a further cobalt reduction in layered oxides and other cobalt- and nickel-free cathode materials are introduced, revenues from the recycled raw materials can be expected to decrease. This might lead to a situation where the recycling of batteries does not cover its own expenses. According to the producer responsibility principle implemented in Directive 2006/66/EC, battery producers or third parties acting on their behalf must finance the net cost of collecting, treating and recycling. As producers will include these additional costs in their battery prices, price savings through cheaper raw materials like iron and manganese might be compensated. In conclusion, the overall monetary life cycle costs might not be reduced. Also, regarding the environmental impact, the life cycle has to be analyzed critically. Due to high process complexities and long process chains, the recycling of specific materials does not necessarily offer an ecological advantage in comparison to the primary production of these raw materials. This is likely the case for raw materials with a comparatively low specific ecologic impact like iron.

From a technological point of view, the processes vary significantly regarding scope of input batteries, applied process designs and state of development. Due to the complex input material, all processes are characterized by long process chains containing combinations of mechanical and/or thermal and/or pyrometallurgical and/or hydrometallurgical unit operations [71].

A particular challenge is the high reactivity of the electrolyte, which reacts violently with oxygen, leading to fire hazards. Due to the fluorine content of the electrolyte, the combustion fumes contain hydrogen fluoride and other highly toxic compounds and therefore pose serious health and environmental risks. To deal with these problems, different approaches have been developed including direct smelting of cells (see Umicore Battery Recycling Process), vacuum thermal deactivation, mechanical treatment under protective atmosphere (see LithoRec Process) and cryogenic processing [12,71].

Regarding process design, two contrary philosophies can be identified. On one side there are processes that are designed to cope with all battery chemistries in one process. In addition, these processes are often capable of processing other materials containing similar target metals. Therefore, these processes tend to focus on the recovery of raw materials, high throughput, and are characterized by early stage standardization. Usually, in these process routes, the battery cells enter a pyrometallurgical treatment with minimum or without mechanical pretreatment followed by further treatment of the process outputs (alloy, slag, flue dusts) mainly by hydrometallurgical processes to recover the individual metals [72]. 
On the other side of the spectrum, the processes are individually adapted to each battery chemistry. These processes tend to focus on the extraction of compounds either for functional recycling, reuse or for specific treatment. This possibly enables higher quality recycling regarding the waste hierarchy in comparison to more universal approaches like those aforementioned. However, it inevitably leads to high requirements regarding collection and sorting as well as knowledge about cell construction and chemistry. Typically, only business-to-business (B2B) relationships can meet all these requirements. Consequently, these processes are unsuitable for mixed battery inputs, e.g., LIB charges from portable battery sorting [72].

In the following, two processes will be briefly described. These are the Umicore Battery Recycling Process and the LithoRec Process. They constitute different manifestations of the spectrum. On one side, the Umicore Battery Recycling Process represents a universal recycling approach, which can process all LIB types and NiMH batteries within certain limitations. On the other side, the LithoRec Process exemplarily shows a highly specific treatment for each LIB chemistry with a strong focus on compound recovery. For a more comprehensive overview of existing recycling processes see [12,71].

\section{Umicore Battery Recycling Process}

The Umicore Battery Recycling Process is one of the most advanced recycling processes for NiMH and LIBs. It is based on a combination of pyrometallurgical and hydrometallurgical unit operations (Figure 5) without mechanical pretreatment of battery cells. The process is mainly designed to recover nickel, cobalt and copper as an alloy, which is further processed by hydrometallurgical methods. Lithium and REEs can be recovered from the slag fraction. A first pilot plant was run in Hofors (Sweden) for a couple of years. Based on experiences from this plant, a second generation pilot plant with an annual capacity of 7000 thas been put into operation in 2011 in Hoboken (Belgium) [71,73].

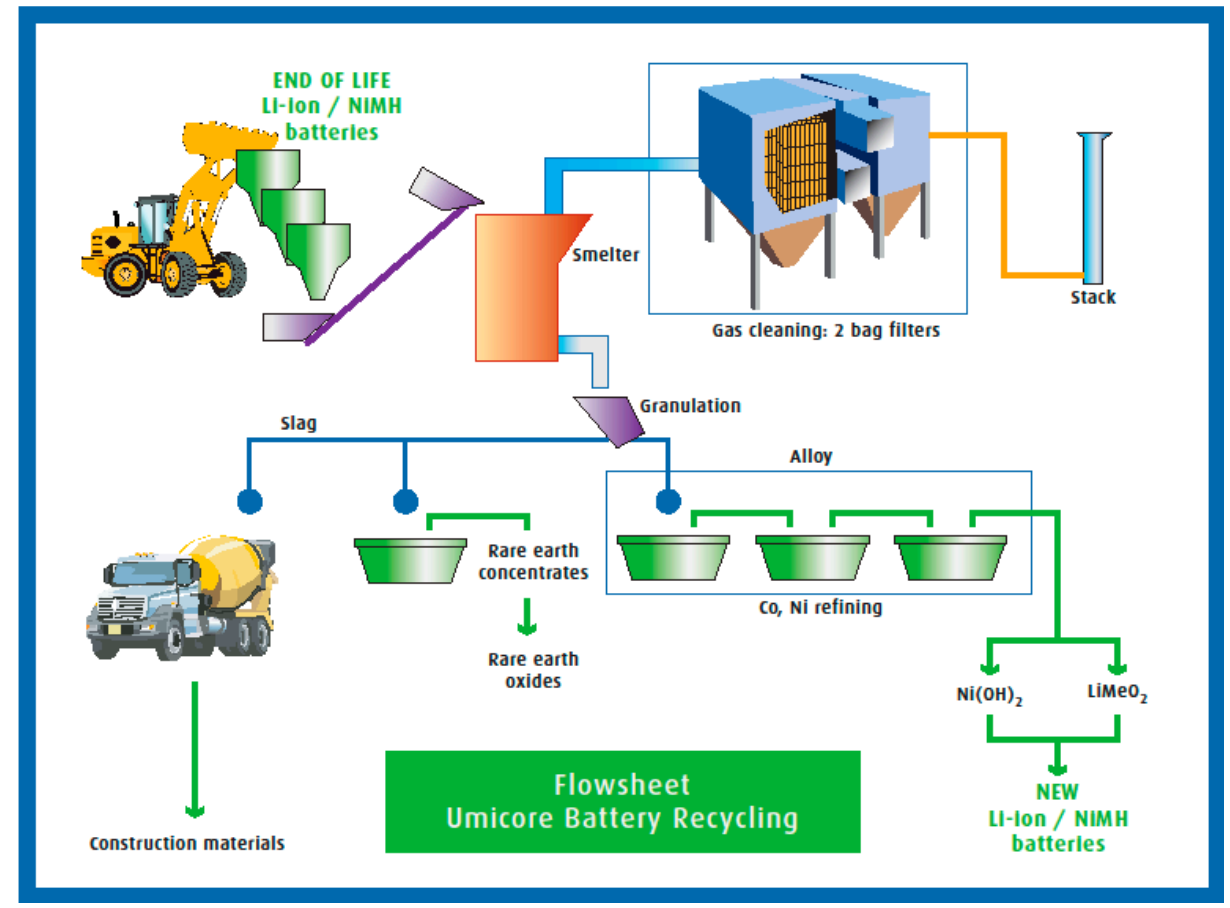

Figure 5. Simplified flow sheet of the Umicore Battery Recycling Process. With permission of Umicore AG \& Co. KG. 
Without further pretreatment, the battery cells are filled into a shaft furnace with slag formers. The redox potential is kept at a level where cobalt, nickel and copper are completely converted into the alloy fraction. Lithium, aluminum and, if applicable, manganese are concentrated in the slag fraction as well as REEs from NiMH batteries. Further elements, especially halogens, are concentrated in the fine dusts $[5,69,73]$.

The alloy, containing mainly cobalt, nickel and copper, is further refined by hydrometallurgical treatment including dissolution of the alloy, copper recovery and nickel/cobalt separation by solvent extraction. After separation and raffination, cobalt and nickel can be converted into precursor chemicals for new cathode materials [69].

The slag is completely inert and non-hazardous and is currently used as a construction material [69]. A lithium recovery from the slag was investigated in lab scale within the research project "Lithium Battery Recycling Initiative (LiBRI)", which was sponsored by the German Federal Ministry for the Environment, Nature Conservation, Building and Nuclear Safety. The investigations revealed that lithium can be leached from the slag using diluted sulfuric acid. After a subsequent precipitation of impurities from the leach liquor, lithium can be recovered as lithium carbonate. For details see Elwert et al. [73]. When processing pure NiMH batteries, REEs can also be leached from the slag and further refined to produce pure REE oxides [69].

The gas emissions are treated by a gas cleaning installation which ensures that no harmful dioxins or volatile organic compounds are produced. It also captures fluorine and collects all possible dust carry-over [69].

The main advantages of the process are its robustness with regard to the battery input, the absence of a mechanical pretreatment of battery cells, and the high recovery rates for cobalt, nickel and copper. The main disadvantage of the process is that it is not an ideal solution for cobalt and nickel-free batteries as only copper and, in the future, maybe lithium are recovered from these batteries. Furthermore, metallic aluminum, which is used as a reductant in the pyrometallurgical treatment, ends up as a low value construction material.

\section{LithoRec Process}

The following battery recycling process was developed within the research projects LithoRec I (2009-2011) and LithoRec II (2012-2015), which were both financially supported by the German Federal Ministry for the Environment, Nature Conservation, Building and Nuclear Safety. The project consortium currently works on a demonstration plant at the Technical University of Braunschweig that will start operation in fall 2015. A start-up company (Lion-Engineering) was founded in order to implement the process industrially [5,74-76].

Figure 6 shows a typical process scheme for the thermo-mechanical process as patented by the consortium [77]. In the beginning, the battery cells undergo a shredding stage with inert gas and a heating stage for electrolyte evaporation. These stages are ideally connected to condensers that allow the recycling of pure electrolytes and additional processing stages for conductive salt recycling (typically $\mathrm{LiPF}_{6}$ ) [76,78]. 


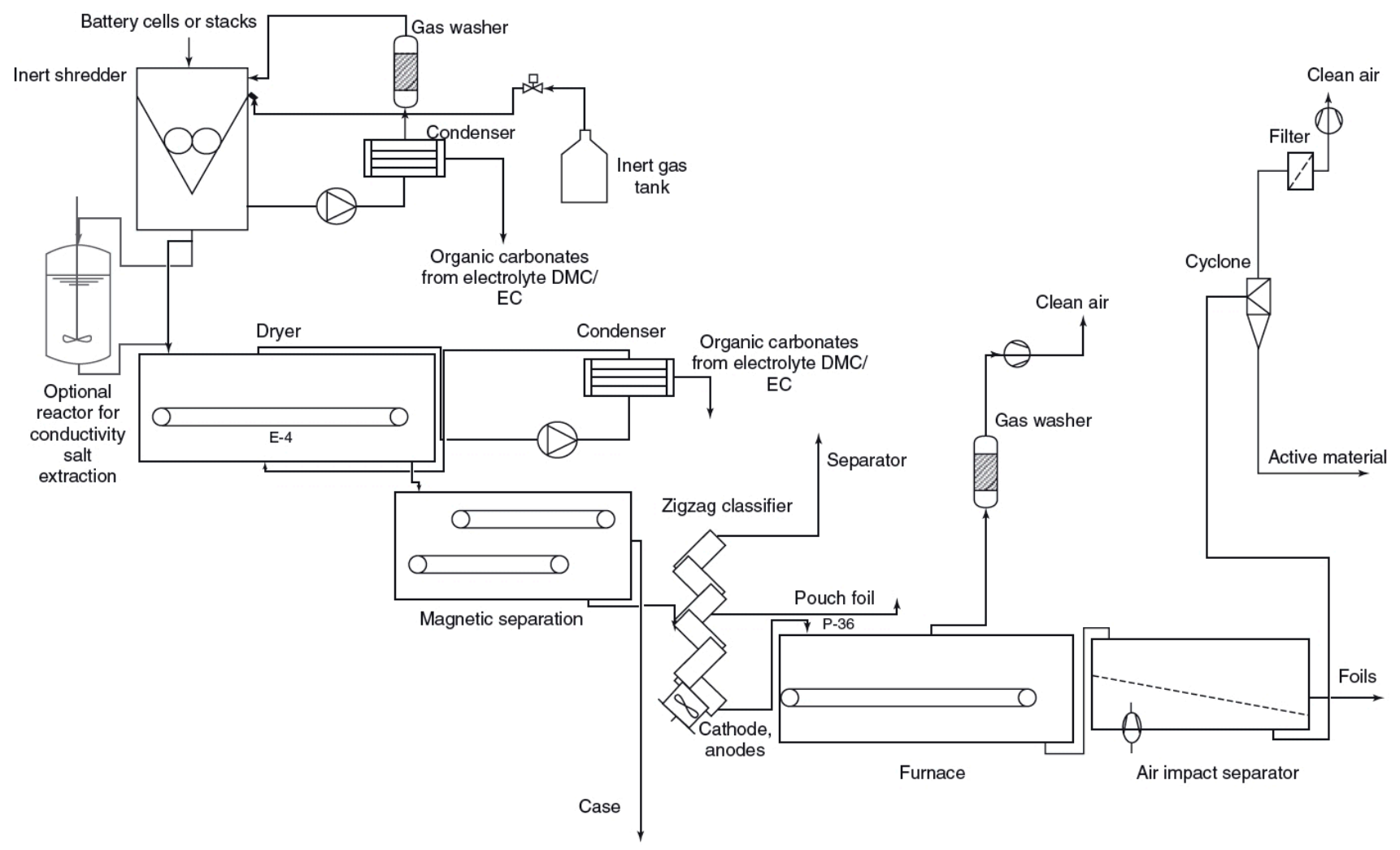

Figure 6. Flow sheet of the thermo-mechanical recycling process LithoRec. Reproduced with permission from Hanisch, C., Handbook of Clean Energy Systems; published by John Wiley \& Sons, Ltd., 2015 [12].

Thereafter, the shredded material enters physical separation which includes magnetic separation for the casings and density separation for copper and aluminum foils. The cathodes and anodes are transferred to the high density fraction and are treated in a furnace $\left(400-600^{\circ} \mathrm{C}\right)$ as well as a special air jet sieve in order to disengage the active material and foil compound and to win back the finely dispersed active material via a cyclone [77].

The separated active material can be introduced in further recycling processes to either directly produce battery materials or the individual elements (lithium and the transition metals). Different routes are feasible and have been investigated. For example, within the LithoRec I project, a hydrometallurgical process that can recycle $85 \%$ of the lithium from $\mathrm{LiFePO}_{4}$ and $95 \%$ of the lithium from $\mathrm{LiNi} 0.33 \mathrm{Mn} 0.33 \mathrm{Co} 0.33 \mathrm{O}_{2}$ active material was developed $[12,67,75]$. The process route is shown in Figure 7.

In contrast to the described process above, the LithoRec Process is designed to win back many compounds individually at battery quality. The developing consortium therefore puts an emphasis on deep disassembly and sorting. While other processes might suffer heavily from the trend that producers aim at reducing nickel and cobalt in LIBs, this process can also produce some other valuable fractions from battery waste, i.e., electrolytes, conductive salts, lithium and active materials. On the other hand, the LithoRec Process is sensible to changes in the input stream and has to implement many measures to control the hazards caused by the electrolytes. Also, there is not yet a market for some of the products mentioned above $[12,72,76,79,80]$. 
For the LithoRec Process, a life cycle assessment (LCA) was conducted [80]. Figure 8 shows the system boundaries of the LCA for the LithoRec Process.

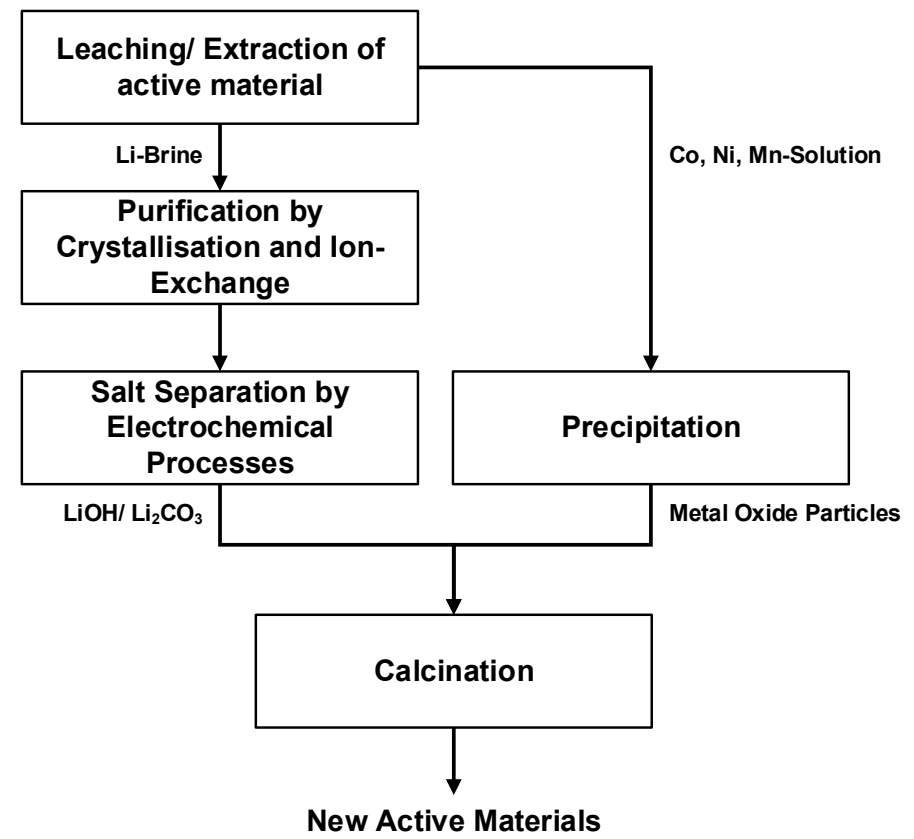

Figure 7. Flow sheet of the hydrometallurgical recycling route of LithoRec. Reproduced with permission from Hanisch, C., Recycling of Lithium Ion Batteries (presentation), 2014 [75].

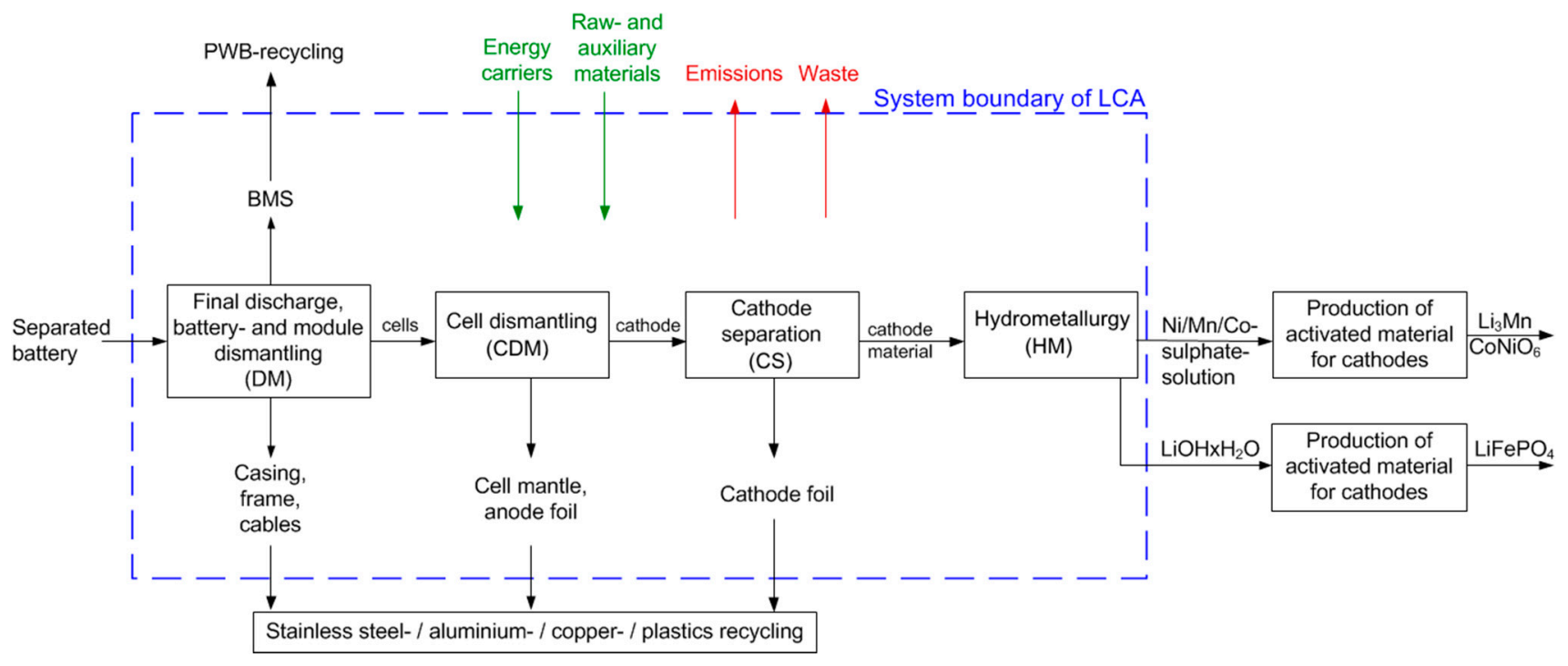

Figure 8. System boundaries of the LithoRec LCA. Adapted from [80].

The LithoRec LCA was conducted according to ISO 14040/44 (International Organization for Standardization), including a critical review by an independent external expert. The LCA is solely based on lab-scale results. The functional unit (FU) was defined as recycling of one ton of batteries (definition of representative battery composition of the cathode types NMC and LFP, respectively). The LithoRec Process aims to yield the following products:

- Suitable starting material for cathode production (Co-/Ni-/MnSO 4 in mixed dilution, $\mathrm{LiOH})$

- Further valuable products $(\mathrm{Cu}, \mathrm{Al}$, stainless steel, plastics) from the battery casing, etc. 
In the following Figure 9 the LCA results of the LithoRec Process for the environmental impact category global warming potential (GWP) are shown. The net result (black column) demonstrates a decisive advantage of this recycling process.

Also, the results for the impact category acidification (Figure 10) show a clear net advantage compared to the primary production route of the products.

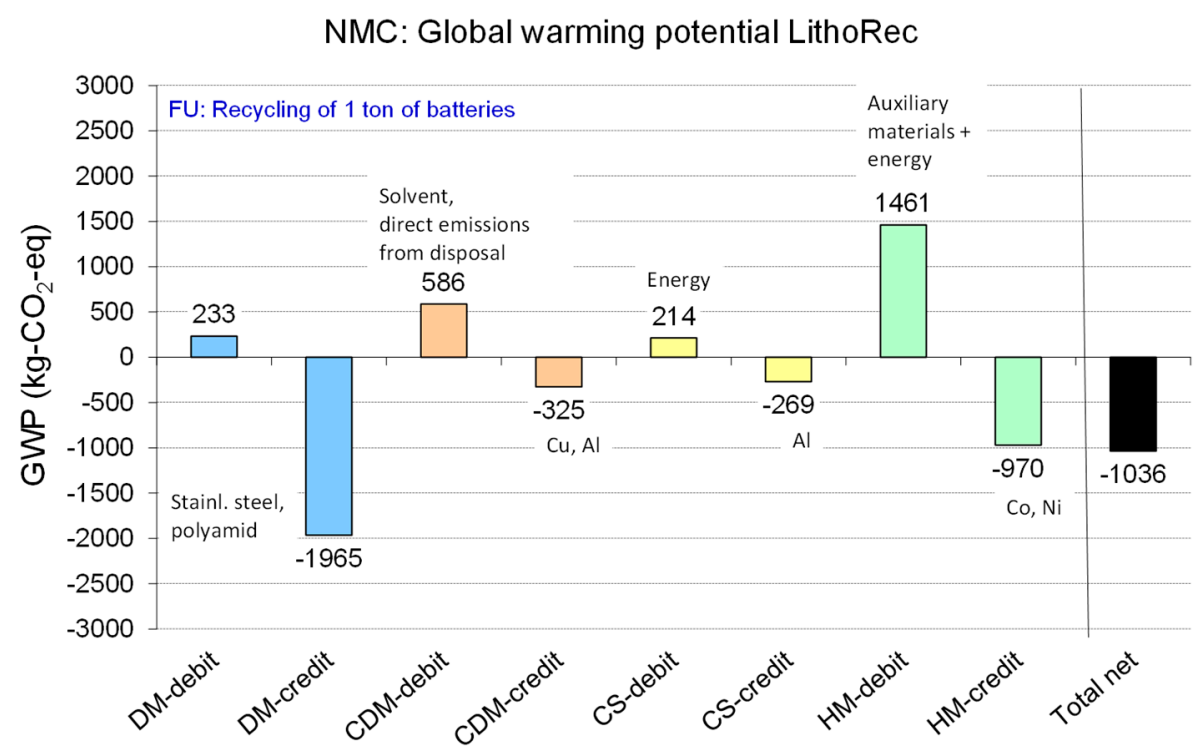

Figure 9. Global warming potential of the LithoRec Process (DM: dismantling (battery and module dismantling), CDM: cell dismantling, CS: cathode separation, HM: hydrometallurgy). Adapted from [80].

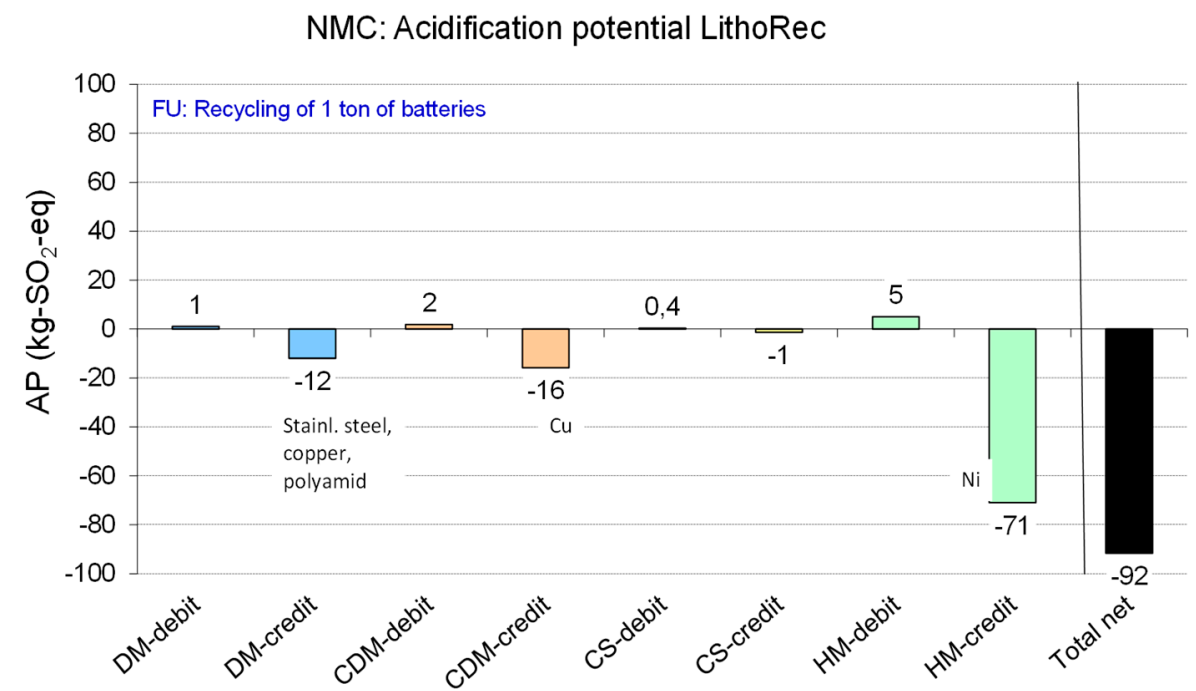

Figure 10. Acidification potential of the LithoRec Process. Adapted from [80].

The results for all environmental impact categories (global warming potential (GWP), non-renewable cumulative energy demand (CED n.r.), abiotic depletion potential (ADPelem), acidification potential (AP), euthrophication potential (EP), and photochemical ozone creation potential (POCP)) show net benefits for the overall recycling process. For GWP and CED n.r. there is a burden for the single-step hydrometallurgy which is compensated by benefits from the dismantling step. For NMC 
the net benefit is higher compared to LFP due to higher relevance of Ni and Co credits. It should be emphasized again that the complete LCA data for the LithoRec Process and the respective results are solely based on lab-scale data. Therefore, the good environmental performance of the LithoRec Process has to be verified in future LCA studies for a pilot or even industrial-scale recycling process.

\subsection{Electric Drive Motors}

As explained above in Section 3.2, the disassembly down to the rotor stator level of motors is economically feasible and the major components (copper, steel, aluminum) can be fed into conventional recycling routes [68]. As the magnet-containing rotors follow the steel recycling route, the REEs are lost to the slag. Therefore, dismantling of the magnets is necessary for REE recycling. So far, no large-scale dismantling method has been put into practice.

Within the MORE project, this problem was addressed by the Institute for Factory Automation and Production Systems of the Friedrich-Alexander-University Erlangen-Nuremberg. Magnets are either mounted on the surface (surface-mounted permanent magnets, SPM) or in pockets close to the rotor surface (integrated permanent magnets, IPM), and therefore require different dismantling techniques. If necessary, the magnets must be uncovered prior to extraction, e.g., by removal of the bandage in case of SPM rotors. In Figures 11 and 12, a complete rotor, a rotor segment and some dismantled magnets are depicted exemplarily for both SPM- and IPM-equipped rotors [6].
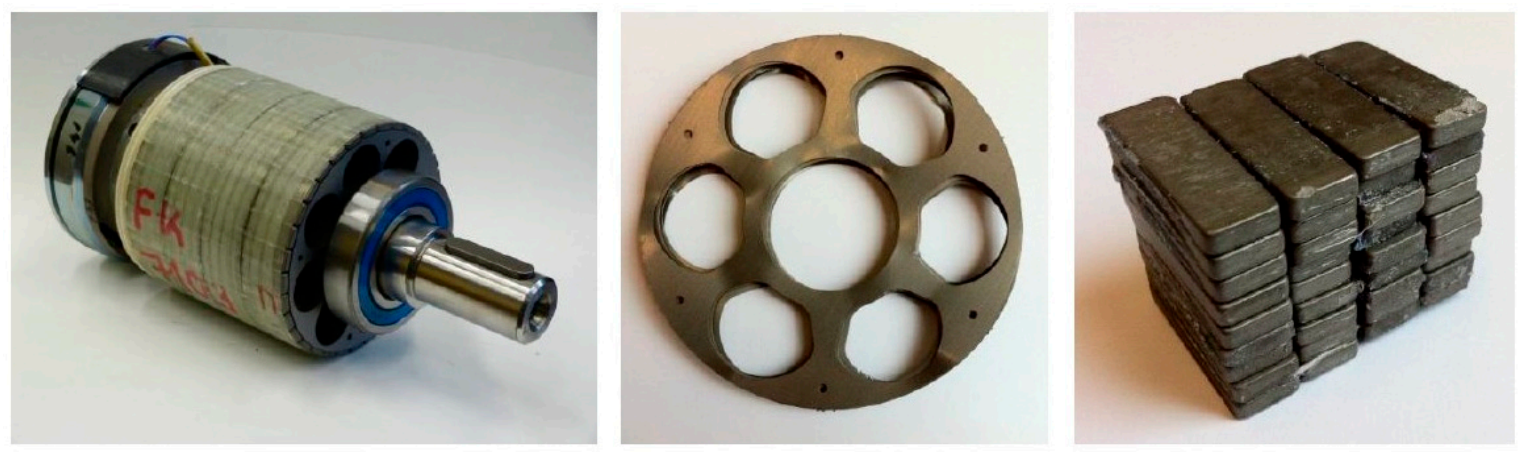

Figure 11. Rotor, rotor segment and dismantled magnets (left to right) of a SPM rotor [6]. Reproduced with permission of Siemens AG.
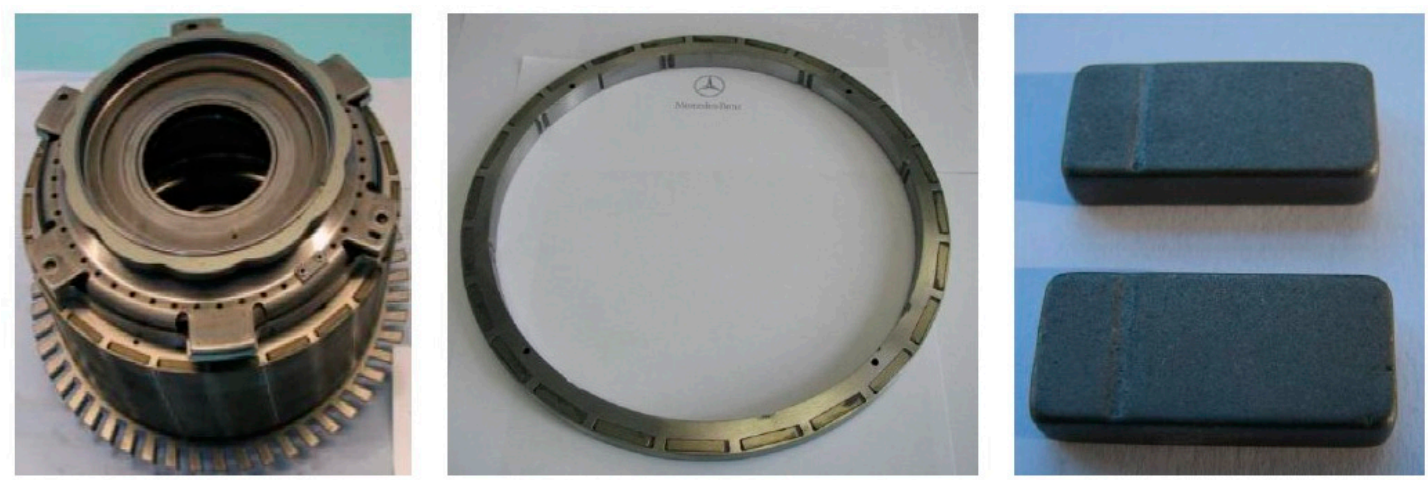

Figure 12. Rotor, rotor segment, dismantled magnets (left to right) of an IPM rotor [6]. Reproduced with permission of Daimler AG. 
Within the framework of the MORE project, different approaches have been followed for dismantling. In the end, two prototype machines were designed and tested which both focus on mechanical dismantling. Magnet losses are below 1\%. The magnets need not to be demagnetized prior to dismantling. In fact, in the case of SPM, the thermal treatment may lead to damaged magnets [81-83].

IPM magnets are pressed out of their rotor segments by a rotor-specific ejector (Figure 13). Via an unmagnetic slide, they are led to a conveyor belt with integrated demagnetization by infrared radiation [6]. SPM magnets are shorn off (Figure 14) and transported to a storage chamber that sorts magnets by polarity and stacks them separately with the help of plastic plates [81].

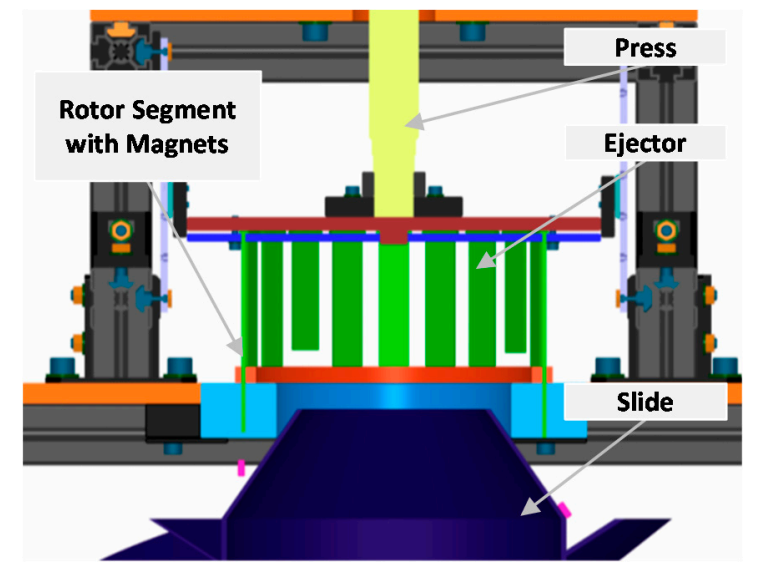

Figure 13. Concept for the dismantling of IPMs [84]. Reproduced and adapted with permission from Klier, T., "MORE"-a project on recycling of components and strategic metals of electric drive motors (presentation), 2015.

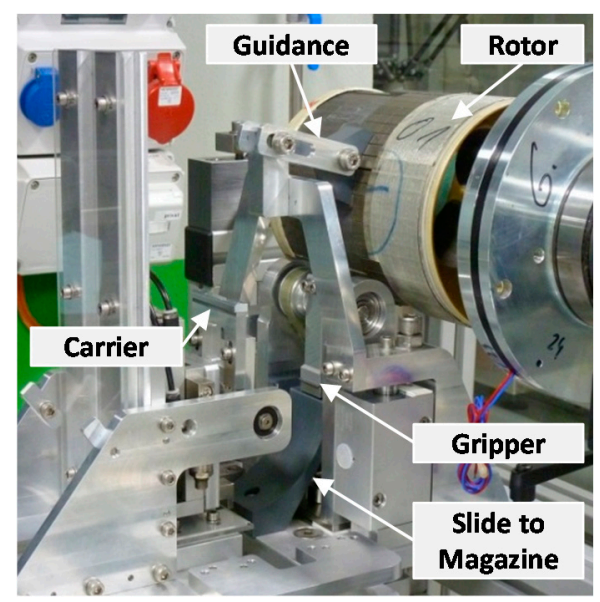

Figure 14. Demonstration set-up for the dismantling of SPMs [84]. Reproduced and adapted with permission from Klier, T., "MORE"- a project on recycling of components and strategic metals of electric drive motors (presentation), 2015.

After dismantling and, if necessary, demagnetization, the magnets can theoretically be processed in a recycling plant. However, currently the recycling of $\mathrm{NdFeB}$ magnets does not exist outside China where mainly production wastes are recycled. As China is the main producer of $\mathrm{NdFeB}$ magnets (market share $>80 \%$ ), sufficient quantities are available. Recycling of post-consumer scrap hardly takes place anywhere and is estimated by the United Nations Environment Programme (UNEP) to be 
below $1 \%$ [85]. The main reasons for this are an inefficient collection, technical difficulties to extract the magnets from many applications, and a lack of economic incentives. However, due to the REE supply situation outside China, different recycling concepts are under investigation including the reuse of magnets, the reuse of the magnetic alloy, and raw material recovery [86].

Regarding the reuse of $\mathrm{NdFeB}$ magnets from electric drive motors, investigations within the MORE project revealed that there is no demagnetization during operation and magnet properties are not changing. Furthermore, the determination of physical properties of dismantled magnets before and after demagnetization and cleaning proved that all magnets tested were suitable for direct reuse as long as the surface was undamaged. Therefore, reuse is theoretically possible, but was not considered a practical option by the project partners due to the technical progress materials and design will make during the life span of a $(\mathrm{H}) \mathrm{EV}$ generation [6].

Also, the reuse of the magnetic alloy in different processing steps in the magnet production (Figure 15) was investigated within the MORE project by the project partner Vacuumschmelze, partly at an industrial scale. For the investigations, which included remelting, solely mechanical crushing, and hydrogen decrepitation with subsequent crushing, dismantled and cleaned magnets were used. In all routes, the inevitable introduction of a certain amount of impurities (mainly carbon and oxygen) leads to remanence losses caused by the formation of oxides and carbides in comparison to magnets produced from solely primary materials. The determined remanence losses were about $1 \%$ per $10 \%$ recycling material used. Further drawbacks are the low yields of $70 \%$ to $80 \%$ in the remelting route, low crushing rates in direct reprocessing without previous hydrogen decrepitation, and the need for magnet scrap of known and homogeneous chemical composition. Due to the limited space and required lightweight design, electric motors for $(\mathrm{H}) \mathrm{EV}$ require magnets with the highest possible remanence. Therefore, and because of the other mentioned drawbacks, reprocessing of the magnetic alloy was also not considered a realistic recycling option within the framework of electromobility [6].

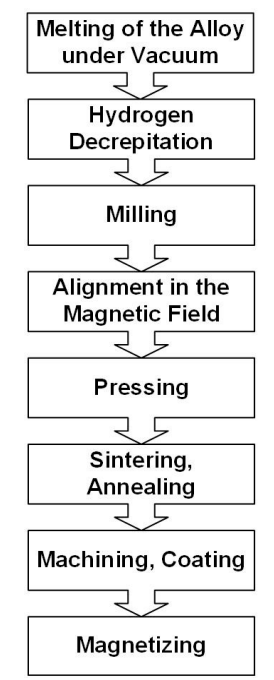

Figure 15. Powder metallurgical production of NdFeB magnets [30].

Although the costliest alternative in terms of economic and ecological expenses, raw material recovery was finally considered the best recycling option for $\mathrm{NdFeB}$ magnets by the MORE project. The main reason for this is that the produced secondary metals (REE metals, cobalt etc.) have the same 
properties as metals from primary production and therefore do not compromise the magnetic properties. For this purpose, two hydrometallurgical processes (Figure 16) were developed up to small pilot scale, which produced mixed and partly separated REE oxides, respectively. These oxides can subsequently be reduced to the respective REE metals, either by metallothermic reduction or molten salt electrolysis, and returned to the magnet production [6,87-89].

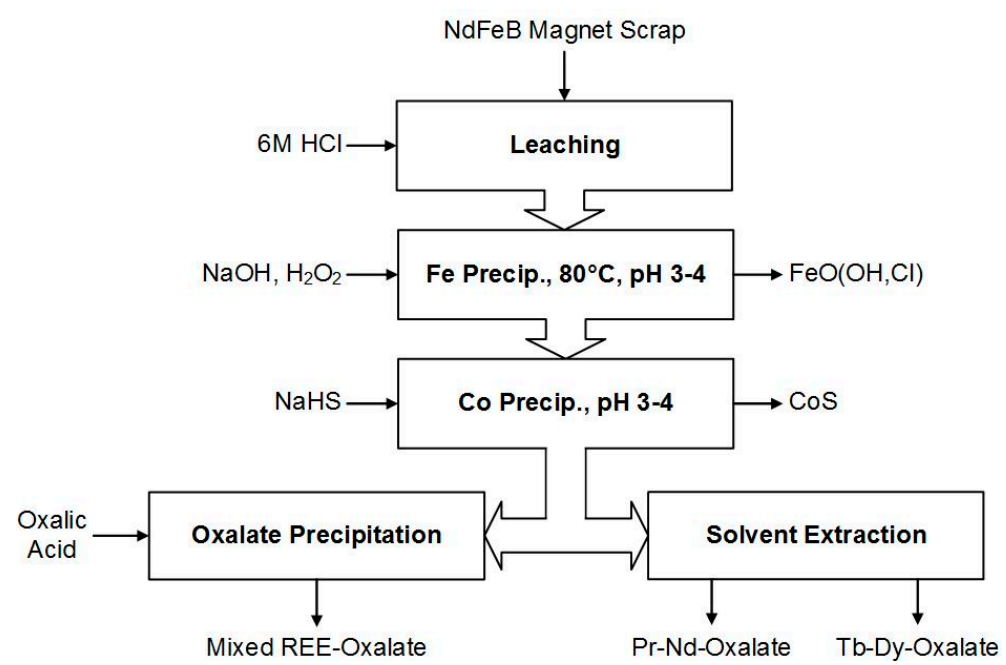

Figure 16. Simplified flow sheet of the hydrometallurgical recycling processes for sintered NdFeB magnets. Adapted from [6].

In both processes, the magnets are firstly dissolved in hydrochloric acid. Subsequently, the leach liquor is purified by the precipitation of iron as akaganeite $(\mathrm{FeO}(\mathrm{Cl}, \mathrm{OH}))$ and cobalt as cobalt sulphide (CoS). In the first process, the REEs, which are praseodymium $(\mathrm{Pr})$, neodymium $(\mathrm{Nd})$, terbium $(\mathrm{Tb})$ and dysprosium (Dy), are recovered after purification in one mixed concentrate by oxalate precipitation. After washing and drying, the oxalates can be converted into the oxides by thermal decomposition. In the second process, the REEs are completely separated by solvent extraction with an organophosphorus extractant (PC-88A) in light and heavy REEs. At the moment, a complete separation at least in light and heavy REEs is necessary for the typically employed reduction and refining methods for $\mathrm{Pr}, \mathrm{Nd}, \mathrm{Tb}$ and $\mathrm{Dy}$ due to their different physical properties such as melting points. Nevertheless, the reduction of a mixed Pr-Nd-Tb-Dy-oxide is thermodynamically possible, but would require the development of an adapted reduction process, which was not part of the MORE project [6,87-89].

Although the MORE project suggested that a recycling of REE from $\mathrm{NdFeB}$ magnets is economically feasible, a short-term industrial realization cannot be expected due to the low available amounts of magnet scrap. Furthermore, at the moment, no reduction plants operate outside China. In the mid- and long-term, the recycling of $\mathrm{NdFeB}$ magnets will probably take place, especially considering the future dismantling of gearless wind turbines in addition to electromobility and other applications [6].

Within the MORE project, the reuse of magnets, the reuse of the magnetic alloy, and raw material recovery were investigated. LCA results are available for all three different routes [81]. In this article, only an excerpt of the LCA results for the raw material route is presented as it was identified as the 
most promising approach. The MORE LCA was again conducted according to ISO 14040/44, including a critical review by an independent external expert, and is based on small pilot-scale data.

Figure 17 shows the system boundaries of the LCA for the recovery of pure neodymium and dysprosium oxide via a final solvent extraction step.

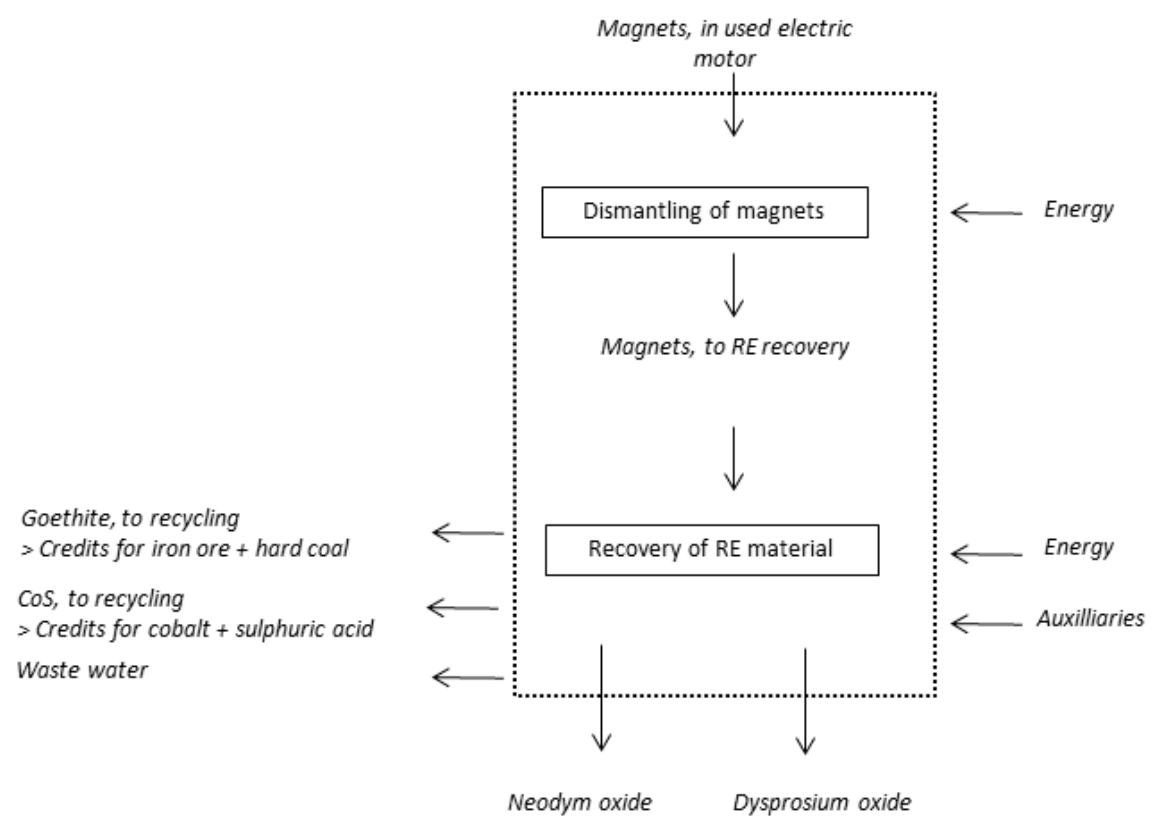

Figure 17. System boundaries of the MORE LCA (recovery of pure neodymium and dysprosium oxide). Adapted from [81].

For the different LCAs conducted for the different MORE process routes, the partners agreed upon the generic composition of a typical NdFeB magnet, which is given in Table 6.

Table 6. Generic composition of the NdFeB magnets for the MORE LCA. Adapted from [81].

\begin{tabular}{cc}
\hline Element & Mass Percentage \\
\hline $\mathrm{Fe}$ & 67 \\
$\mathrm{~B}$ & 1 \\
$\mathrm{Co}$ & 2 \\
$\mathrm{Nd}$ & 20 \\
$\mathrm{Dy}$ & 10 \\
\hline
\end{tabular}

The functional unit for this LCA is defined as the recovery of $1 \mathrm{~kg}$ REE oxide (Nd:Dy ratio $=2: 1$ ). It should be highlighted that for the credit calculation for the recovered REEs, a mass allocation as well as an economic allocation was used (see data in Table 7).

Table 7. Comparison of primary Nd and Dy production data * (GWP). Adapted from [81].

\begin{tabular}{clc}
\hline Allocation approach & Nd & Dy \\
\hline & $(\mathrm{kg} \mathrm{CO}$-eq./kg REE $)$ \\
Economic allocation ** & 131 & 1159 \\
Mass allocation & 35 & 35 \\
\hline
\end{tabular}

* PE international data for MORE, 2013; ** REE prices in summer 2013. 
The following Figure 18 demonstrates the LCA results for the recovery of pure neodymium and dysprosium oxide compared to the primary production route. The necessary additional step from REE oxide to REE metal was taken into account for this calculation.

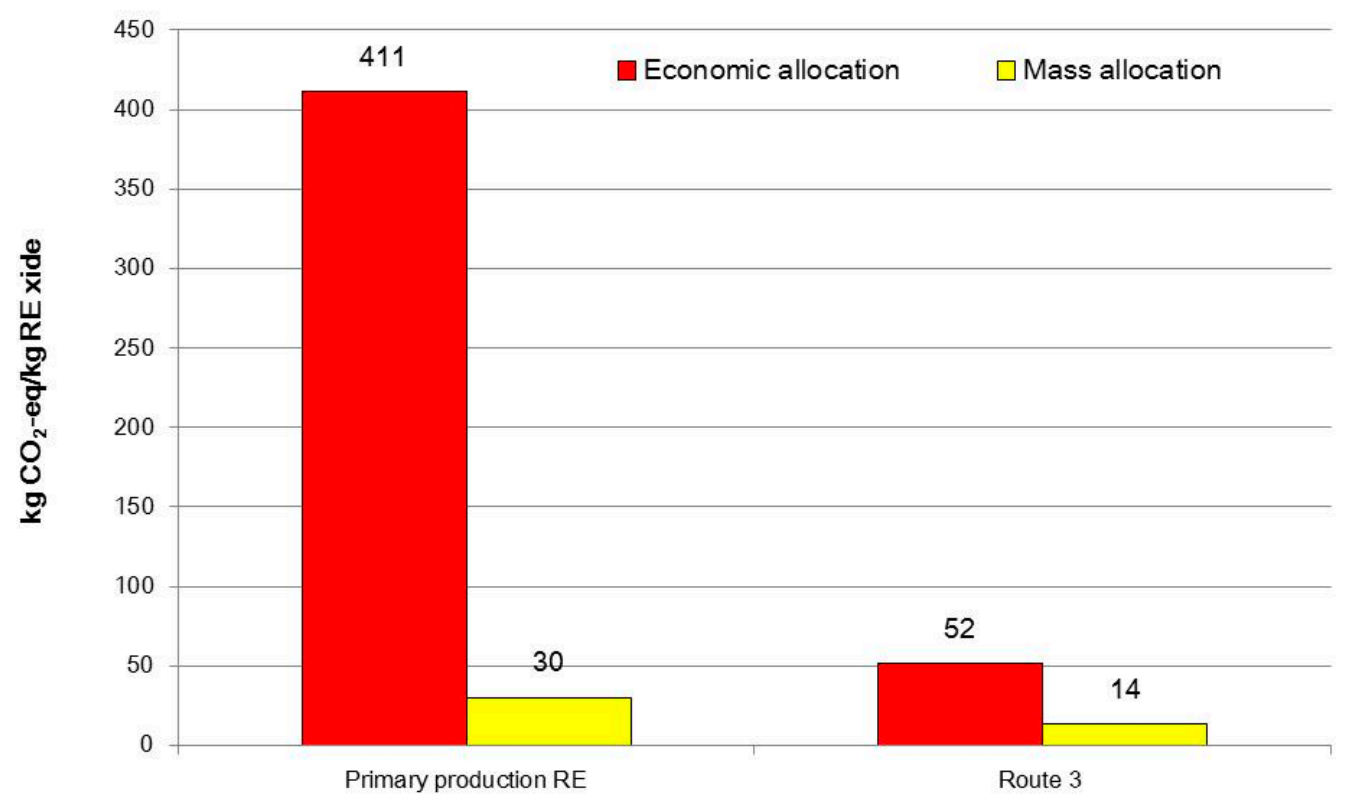

Figure 18. Global warming potential, recovery of pure neodymium and dysprosium oxide (solvent extraction route). Adapted from [81].

Also, the results for all other environmental impact categories show net benefits. Therefore, the overall recycling process seems to be very promising from an ecological point of view in comparison to the primary production of REEs. However, the good environmental performance should be verified in future LCA studies if further scale-up takes place, especially considering that the collection of comprehensive LCA data for the primary routes of rare earth elements is a pending and challenging task.

\subsection{Power Electronics}

Currently, only one research project, in which the authors are involved, deals with the recycling of power electronics from $(\mathrm{H}) E V$ s. The project is called "Recycling of electric vehicles 2020 Key component power electronics" and is funded by the German Federal Ministry for the Environment, Nature Conservation, Building and Nuclear Safety. First results from this project indicate that current power electronics can be treated similar to normal electronic scrap. That means comminution to liberate the individual components is followed by subsequent classifying and sorting to produce marketable metal concentrates for further metallurgical processing.

However, that does not mean that there is no need for research, as significant changes can be expected in the upcoming years (see Section 2.1.3). For example, the possible integration of power electronics in the electric motor would require new dismantling concepts. Another challenge could emerge from the use of $\mathrm{GaN}$ semiconductors instead of SiC- or Si-based semiconductors. As the gallium market is comparatively small, noticeable effects can be expected in case of a strong market penetration [9]. First investigations on the recycling of gallium nitride-containing semiconductors indicate that an efficient and economic gallium extraction will be difficult to achieve due to the low 
gallium amount per unit and complex assemblies. Furthermore, it should be noted that today's electronic scrap recycling processes have a strong focus on copper and precious metals and are not capable of recovering many other electronic metals like antimony and tantalum, for instance [90].

\section{Discussion and Conclusions}

The introduction of electromobility is causing major challenges for the recycling industry. Even though the return flow of electric ELVs is small at the moment, considerable changes can be expected in the upcoming years. Nevertheless, a recycling system for electric ELVs has not been established yet and many issues are unsolved. In general, the developments in the field of electromobility are highly dynamic, which is true for vehicle concepts as well as individual components. Therefore, all forecasts are characterized by a high degree of uncertainty.

This paper summarizes the recent developments regarding the key components of every electric vehicle, which are traction battery, electric motor and power electronics. Some general trends could be identified for all components. Firstly, new materials, in our case metals, are introduced to the power train. Some of them are classified as critical (cobalt, REEs, palladium, antimony, gallium) and are lost in shredding or post-shredding sorting without proper dismantling and designated recycling routes. Secondly, the components are produced in a great variety with little standardization and inadequate design for recycling. This might change over the next decade, but this imposes many problems on disassembly and dismantling of components as automatization is difficult to implement. Thirdly, in all discussed components, decreasing contents of high-value materials can be expected within the upcoming years, e.g., batteries with low or no cobalt and nickel content, NdFeB magnets with reduced dysprosium content, as well as more compact power electronics units. Therefore, lower revenues from recycling have to be expected at least in some cases. Fourthly, solely mass-oriented recycling quotas do not necessarily suffice as an adequate legislative steering instrument. On one hand, they do not give an incentive to recycle minor metals (e.g., gallium, antimony in electronics) and might lead to un-ecological recycling systems, such as in the case of Co and Ni-free batteries.

Regarding the development of recycling concepts for the individual components, there is a strong research focus on traction batteries due to their high weights, energy contents, and potential dangers. In contrast, there are only very few specific recycling activities in the fields of electric motors and power electronics. However, one has to consider that there are many activities on the recycling of $\mathrm{NdFeB}$ magnets and waste electric and electronic equipment in general, shifting the key challenge to dismantling.

Besides mentioned difficulties, batteries bear considerable hazards in terms of inflammability, the possible formation of harmful substances, and electric energy content. Therefore, the requirements concerning safety, personnel, and environmental protection are particularity high, resulting in high costs. Current recycling processes for LIB cells focus on the recovery of cobalt, nickel, and copper due to their comparatively high prices and ease of recovery in pyrometallurgical processes. Other elements are mostly not recovered or undergo down-cycling. As the Co and $\mathrm{Ni}$ content will supposedly decrease, more sophisticated approaches will rise in importance in order to increase the overall added value by the recycling of more elements and even components. However, the latter is complicated by the variety of battery chemistries. 
At least in the near future, permanent magnet motors will be the predominant technology for (H)EVs, assuming no extreme price increases for neodymium and dysprosium occur. The recycling of electric motors is state-of-the-art whereby mainly steel and copper are recovered. REEs from NdFeB magnets are lost to the steel recycling route in this practice. Therefore, establishing a REE recycling process is the major challenge. To overcome this challenge, the industrial implementation of efficient magnet extraction processes for different rotor types as well as the actual recycling processes is necessary. For both problems, possible solutions exist at small pilot scale, but industrial realization cannot be expected before 2020. Further challenges might derive from the integration of power electronics in the electric motor as well as new installation positions which could impede disassembly.

Similar to electric motors, power electronics can be recycled in established recycling processes (WEEE). Therefore, power electronics can be recycled in principle. The main challenges are the disassembly in case of decentralization and the low recycling quotas for some metals such as tantalum, REEs, antimony and gallium.

The accompanying LCA studies carried out within the LithoRec and MORE projects delivered promising results for the recycling processes under R\&D for Li-ion batteries and electric drive motors. In the case of a realization or up-scaling of these processes, accompanying LCA studies are again recommended for getting in-depth information about optimization potentials of the different recycling processes.

\section{Acknowledgments}

The projects "Lithium ion battery recycling initiative (LiBRi)", "LithoRec I \& II" and "Recycling of electric vehicles 2020-Key component power electronics" were/are financially supported by the German Federal Ministry for the Environment, Nature Conservation, Building and Nuclear Safety. The project "Recycling of components and strategic metals from electric drive motors" was financially supported by the German Federal Ministry of Education and Research.

\section{Author Contributions}

Daniel Goldmann conceived the paper with Tobias Elwert and initiated the research projects "LiBRi", "MORE" and "Recycling of electric vehicles 2020-Key component power electronics" with the respective project partners. Doris Schueler performed the investigations on power electronics and wrote chapter 2.1.3. Cornelia Merz designed and calculated the LCA for the LithoRec Process, Juergen Sutter for the MORE project. Matthias Buchert supervised both LCAs and wrote the LCA parts in this paper. Felix Roemer and Tobias Elwert wrote all other chapters and prepared the manuscript.

\section{Conflicts of Interest}

The authors declare no conflict of interest.

\section{References}

1. Khajepour, A.; Fallah, M.S.; Goodarzi, A. Electric and Hybrid Vehicles. Technologies, Modeling and Control: A Mechatronic Approach; Wiley: Chichester, UK, 2014. 
2. Pistoia, G. Electric and Hybrid Vehicles. Power Sources, Models, Sustainability, Infrastructure and the Market, 1st ed.; Elsevier: Amsterdam, the Netherlands, 2010.

3. Warner, J. Lithium-Ion Battery Packs for EVs. In Lithium-Ion Batteries; Elsevier: Amsterdam, the Netherlands, 2014; pp. 127-150.

4. Vuorilehto, K. Materialien und Funktion. In Handbuch Lithium-Ionen-Batterien; Korthauer, R., Ed.; Springer Berlin Heidelberg: Berlin, Germany, 2013; pp. 21-29.

5. Treffer, F. Entwicklung Eines Realisierbaren Recyclingkonzeptes für die Hochleistungsbatterien Zukünftiger Elektrofahrzeuge: Lithium-Ionen Batterierecycling Initiative-LiBRi; Final Research Report, 2011. Available online: http://edok01.tib.uni-hannover.de/edoks/e01fb12/727409611.pdf. (accessed on 16 September 2015).

6. Bast, U. Recycling von Komponenten und Strategischen Metallen aus Elektrischen Fahrantrieben: MORE (Motor Recycling); Final Research Report, 2014. Available online: http://edok01.tib. uni-hannover.de/edoks/e01fb15/826920594.pdf (accessed on 16 September 2015).

7. European Commission. Report on Critical Raw Materials for the EU, 2014. Available online: http://ec.europa.eu/DocsRoom/documents/10010/attachments/1/translations/en/renditions/native (accessed on 16 September 2015).

8. Angerer, G.; Marscheider-Weidemann, F.; Wendl, M.; Wietschel, M. Lithium für Zukunftstechnologien: Nachfrage und Angebot unter besonderer Berücksichtigung der Elektromobilität; Frauenhofer ISI: Karlsruhe, Germany, 2009. Available online: http://www.isi. fraunhofer.de/isi-wAssets/docs/n/de/publikationen/Lithium_fuer_Zukunftstechnologien.pdf (accessed on 16 September 2015).

9. Öko-Institut e.V.; Institut für sozial-ökologische Forschung. OPTUM: Optimierung der Umweltentlastungspotenziale von Elektrofahrzeugen: Integrierte Betrachtung von Fahrzeugnutzung und Energiewirtschaft; Final Report: Berlin, Germany, 2011. Available online: http://www.oeko.de/ oekodoc/1342/2011-004-de.pdf (accessed on 16 September 2015).

10. Kühn, A.; Novinsky, P.; Schade, W. GLOMO_Global Mobility Model. Available online: http://publica.fraunhofer.de/documents/N-307006.html (accessed on 16 September 2015).

11. Natkunarajhah, N.; Scharf, P. The variety of lithium-ion battery designs in XEV and their impact on the disassembly process. In Proceedings of the Advanced Automotive \& Stationary Battery Conference, Mainz, Germany, 26-29 January 2015.

12. Hanisch, C.; Diekmann, J.; Stieger, A.; Haselrieder, W.; Kwade, A. Recycling of Lithium-Ion Batteries. In Handbook of Clean Energy Systems; Yan, J., Ed.; John Wiley \& Sons, Ltd.: Chichester, UK, 2015; pp. 2865-2888.

13. Köhler, U. Aufbau von Lithium-Ionen-Batteriesystemen. In Handbuch Lithium-Ionen-Batterien; Korthauer, R., Ed.; Springer Berlin Heidelberg: Berlin, Germany, 2013; pp. 95-106.

14. Huang, Z.; Du, G. Nickel-based batteries for medium- and large-scale energy storage. In Advances in Batteries for Medium and Large-Scale Energy Storage; Elsevier: Amsterdam, the Netherlands, 2015; pp. 73-90.

15. Graf, C. Kathodenmaterialien für Lithium-Ionen-Batterien. In Handbuch Lithium-Ionen-Batterien; Korthauer, Ed.; Springer Berlin Heidelberg: Berlin, Germany, 2013; pp. 31-44. 
16. Wurm, C.; Öttinger, O.; Wittkämper, S.; Zauter, R.; Vuorilehto, K. Anodenmaterialien für Lithium-Ionen-Batterien. In Handbuch Lithium-Ionen-Batterien; Korthauer, R., Ed.; Springer Berlin Heidelberg: Berlin, Germany, 2013; pp. 45-60.

17. Hartnig, C.; Schmidt, M. Elektrolyte und Leitsalze. In Handbuch Lithium-Ionen-Batterien; Korthauer, R., Ed.; Springer Berlin Heidelberg: Berlin, Germany, 2013; pp. 61-77.

18. Weber, C.J.; Roth, M. Separatoren. In Handbuch Lithium-Ionen-Batterien; Korthauer, R., Ed.; Springer Berlin Heidelberg: Berlin, Germany, 2013; pp. 79-93.

19. Buchert, M.; Jenseits, W.; Merz, C.; Schüler, D. Verbundprojekt: Entwicklung Eines Realisierbaren Recyclingkonzepts für die Hochleistungsbatterien zukünftiger Elektrofahrzeuge-LiBRi: Teilprojekt: LCA der Recyclingverfahren; Final Report; Darmstadt, Germany, 2011. Available online: http:/www.erneuerbar-mobil.de/de/projekte/foerderprojekte-aus-dem-konjunkturpaket-ii-2009-2011/ batterierecycling/abschlussberichte-recycling/lca-analyse-libri.pdf (accessed on 16 September 2015).

20. Hofman, T. Hybrid drive train technologies for vehicles. In Alternative Fuels and Advanced Vehicle Technologies for Improved Environmental Performance; Elsevier: Amsterdam, the Netherlands, 2014; pp. 567-581.

21. De Santiago, J.; Bernhoff, H.; Ekergård, B.; Eriksson, S.; Ferhatovic, S.; Waters, R.; Leijon, M. Electrical Motor Drivelines in Commercial All-Electric Vehicles: A Review. IEEE Trans. Veh. Technol. 2012, 61, 475-484.

22. Chau, K.T. Pure electric vehicles. Alternative Fuels and Advanced Vehicle Technologies for Improved Environmental Performance; Elsevier: Cambridge, MA, USA, 2014; pp. 655-684.

23. Matthé, R.; Eberle, U. The Voltec System-Energy Storage and Electric Propulsion. In Lithium-Ion Batteries; Elsevier: Amsterdam, the Netherlands, 2014; pp. 151-176.

24. Widmer, J.D.; Martin, R.; Kimiabeigi, M. Electric vehicle traction motors without rare earth magnets. Sustain. Mater. Technol. 2015, 3, 7-13.

25. Orecchini, F.; Santiangeli, A.; Dell'Era, A. EVs and HEVs Using Lithium-Ion Batteries. In Lithium-Ion. Batteries; Elsevier: Amsterdam, the Netherlands, 2014; pp. 205-248.

26. Hutchinson, T.; Burgess, S.; Herrmann, G. Current hybrid-electric powertrain architectures: Applying empirical design data to life cycle assessment and whole-life cost analysis. Appl. Energy 2014, 119, 314-329.

27. Schieffer, T.; Jeffers, M.A.; Hawkins, S.; Heisel, A.; Leahy, C.; Rapa, E.; Twarog, C. Spark EV Propulsion System Integration. In Proceedings of the SAE 2014 World Congress \& Exhibition, Warrendale, PA, USA, 8-10 April 2014.

28. Inside EVs. 2014 Monthly Sales Chart for the Major Plug-in Automakers, 2015. Available online: http://insideevs.com/monthly-plug-in-sales-scorecard/ (accessed on 16 September 2015).

29. Kara, H.; Chapman, A.; Crichton, T.; Willis, P.; Morley, N. Lanthanide Resources and Alternatives. A report for the Department for Transport and the Department for Business, Innovation and Skills, 2010. Available online: http://www.oakdenehollins.co.uk/media/205/ lanthanide_resources_and_alternatives_may_2010.pdf(accessed on 16 September 2015).

30. Katter, M. Entwicklungstrends bei Pulvermetallurgisch Hergestellten Seltenerd-Dauermagneten. In Proceedings of the Workshop Magnetwerkstoffe-Vom Design bis zum Recycling, Bremen, Germany, 19-20 May 2015. 
31. Federal Institute for Geosciences and Natural Resources. Preismonitor. May 2015. Available online: http://www.deutsche-rohstoffagentur.de/EN/Themen/Min_rohstoffe/Produkte/Preisliste/ cpl_15_04.pdf;jsessionid=9A61EBD61E6233799578A87A817D765F.1_cid292?_blob=publication File $\& v=3$ (accessed on 16 September 2015).

32. Liu, R.; Sun, X.; Gong, J.; Guo, S. Comparison of different arrangement of magnets for the purpose of reducing magnet usage in designing an IPM motor for Electric Vehicles. In Proceedings of the IEEE Transportation Electrification Conference and Expo, Asia-Pacific (ITEC Asia-Pacific), Beijing, China, 31 August-3 September 2014; pp. 1-5.

33. Willard, M. Stronger, Lighter, and More Energy Efficient: Challenges of Magnetic Material Development for Vehicle Electricification. In: Frontiers of Engineering; Reports on Leading-Edge Engineering from the 2012 Symposium, National Academy of Engineering; The National Academies Press: Washington, DC, USA, 2013.

34. Morimoto, S.; Ooi, S.; Inoue, Y.; Sanada, M. Experimental Evaluation of a Rare-Earth-Free PMASynRM with Ferrite Magnets for Automotive Applications. IEEE Trans. Ind. Electron. 2014, 61, 5749-5756.

35. Matsuhashi, D.; Matsuo, K.; Okitsu, T.; Ashikaga, T.; Mizuno, T. Comparison study of various motors for EVs and the potentiality of a ferrite magnet motor. In Proceedings of the International Power Electronics Conference (IPEC-Hiroshima 2014 ECCE-ASIA), Hiroshima, Japan, 18-21 May 2014; pp. 1886-1891.

36. Stancu, C.; Ward, T.; Rahman, K.; Dawsey, R.; Savagian, P. Separately excited synchronous motor with rotary transformer for hybrid vehicle application. In Proceedings of the IEEE Energy Conversion Congress and Exposition (ECCE), Pittsburgh, PA, USA, 14-18 September 2014; pp. 5844-5851.

37. Ruff, B.; Li, W.; Venkatasubramanian, R.; Mast, D.; Sowani, A.; Schulz, M.; Harned, T.J. Development of Lightweight Sustainable Electric Motors. In Nanotube Superfiber Materials; Elsevier: Oxford, UK, 2014; pp. 595-626.

38. Jain, M.; Williamson, S.S. Suitability analysis of in-wheel motor direct drives for electric and hybrid electric vehicles. In Proceedings of the Electrical Power \& Energy Conference (EPEC), 22-23 October 2009, Montreal, QC, Canada; pp. 1-5.

39. Murata, S. Innovation by in-wheel-motor drive unit. Veh. Syst. Dyn. 2012, 50, 807-830.

40. Muttana, S.B.; Dey, R.K.; Sardar, A. Trends in Lightweighting of BEVs: A Review of Strategies. Auto. Tech. Rev. 2014, 3, 18-23.

41. Spath, D.; Rothfuss, F.; Hermann, F.; Voigt, S.; Brand, M.; Fischer, S.; Ernst, T.; Loleit, M. Structure Study BWe Mobile 2011: Baden-Württemberg on the Way to Electromobility, 2011. Available online: http:/www.e-mobilbw.de/files/e-mobil/content/DE/Service/Publikationen/ e-papers/e_mobil_structure_study_en/files/mobile/index.html\#1 (accessed on 16 September 2015).

42. Schüler, D. Division Infrastructure \& Enterprises, Oeko-Institut e. V.-Institute for Applied Ecology, Darmstadt, Germany. Personal communication, 2015.

43. Grasshoff, T. Einen Schritt voraus: Aufbau-und Verbindungstechnik optimiert Leistungselektronik. Elektron. J. 2011, 2, 12-14.

44. Eckardt, S. Roundtable im Hochhaus: Galliumnitrid und Siliziumkarbid im Vergleich. Elektron. J. 2011, 2, 16-21. 
45. Shenai, K.; Dudley, M.; Davis, R.F. Current Status and Emerging Trends in Wide Bandgap (WBG) Semiconductor Power Switching Devices. ECS J. Solid State Sci. Technol. 2013, 2, 3055-3063.

46. Fraunhofer Institute for Integrated Systems and Device Technology. Günstigere Elektrofahrzeuge Durch Motorintegrierte Leistungselektronik; Start für Projekt EMiLE: Erlangen, Germany, 2013.

47. Elsner, H. Zinn: Angebot und Nachfrage bis 2020. DERA Rohstoffinformationen, 20; Bundesanstalt für Geowissenschaften und Rohstoffe, Ed.; Berlin, 2014. Available online: http://www.bgr.bund.de/DE/Gemeinsames/Produkte/Downloads/DERA_Rohstoffinformationen/ rohstoffinformationen-20.pdf?_blob=publicationFile \&v=7 (accessed on 16 September 2015).

48. US Geological Survey. Mineral Commodity Summaries 2015. US Geological Survey, 2015. Available online: http://dx.doi.org/10.3133/70140094 (accessed on 16 September 2015).

49. British Geological Survey. Cobalt. Comodity Profile, 2009. Available online: http://www.bgs.ac.uk/ downloads/start.cfm?id=1400 (accessed on 16 September 2015).

50. Minor Metals Trade Association. Cobalt Market Overview. Available online: http://www.mmta.co.uk/cobalt-market-overview (accessed on 7 April 2015).

51. Eurostat. Energy, Transport and Enivonment Indicators; Publications Office of the European Union: Luxenbourg, Luxembourg, 2014.

52. Edwards, C.; Coates, G.; Leaney, P.G.; Rahimifard, S. Implications of the End-of-Life Vehicles Directive on the vehicle recovery sector. J. Eng. Manuf. 2006, 220, 1211-1216.

53. Sakai, S.-I.; Yoshida, H.; Hiratsuka, J.; Vandecasteele, C.; Kohlmeyer, R.; Rotter, V.S.; Passarini, F.; Santini, A.; Peeler, M.; Li, J.; et al. An international comparative study of end-of-life vehicle (ELV) recycling systems. J. Mater. Cycles Waste Manag. 2014, 16, 1-20.

54. Vermeulen, I.; van Caneghem, J.; Block, C.; Baeyens, J.; Vandecasteele, C. Automotive shredder residue (ASR): Reviewing its production from end-of-life vehicles (ELVs) and its recycling, energy or chemicals' valorisation. J. Hazard. Mater. 2011, 190, 8-27.

55. Kohlmeyer, R.; Groke, M.; Sander, K.; Bergamos, M. Perspektiven der zunehmenden Fahrzeugelektronik für das Altfahrzeugrecycling. In Recycling und Rohstoffe; Goldmann, D., Thomé-Kozmiensky, K.J., Eds.; TK-Verlag Karl Thomé-Kozmiensky: Neuruppin, Germany, 2015; pp. 183-205.

56. Holzhauer, R. Altauto-Demontage: Bisherige Entwicklungen und Realität. In Recycling und Rohstoffe; Thomé-Kozmiensky, K.J., Goldmann, D., Eds.; TK-Verlag Karl Thomé-Kozmiensky: Neuruppin, Germany, 2015; pp. 151-171.

57. Ferrão, P.; Nazareth, P.; Amaral, J. Strategies for Meeting EU End-of-Life Vehicle Reuse/Recovery Targets. J. Ind. Ecol. 2006, 10, 77-93.

58. Martens, H. Recyclingtechnik; Spektrum Akademischer Verlag: Heidelberg, Germany, 2011.

59. Ciacci, L.; Morselli, L.; Passarini, F.; Santini, A.; Vassura, I. A comparison among different automotive shredder residue treatment processes. Int. J. Life Cycle Assess. 2010, 15, 896-906.

60. Widmer, R.; Du, X.; Haag, O.; Restrepo, E.; Wäger, P.A. Scarce Metals in Conventional Passenger Vehicles and End-of-Life Vehicle Shredder Output. Environ. Sci. Technol. 2015, 2, doi:10.1021/es505415d.

61. Passarini, F.; Ciacci, L.; Santini, A.; Vassura, I.; Morselli, L. Auto shredder residue LCA: Implications of ASR composition evolution. J. Clean. Prod. 2012, 23, 28-36. 
62. Ahmed, N.; Wenzel, H.; Hansen, J.B. Characterization of Shredder Residues generated and deposited in Denmark. Waste Manag. 2014, 34, 1279-1288.

63. Lieberwirth, H.; Krampitz, T. Entwicklungstendenzen für den Einsatz von Leichtbauwerkstoffen im Fahrzeugbau und Auswirkungen auf das Recycling. In Recycling und Rohstoffe; Thomé-Kozmiensky, K.J., Goldmann, D., Eds.; TK-Verlag Karl Thomé-Kozmiensky: Neuruppin, Germany, 2015; pp. 208-218.

64. Pehlken, A.; Kalverkamp, M. Kaskadennutzung im Automobil: Realität oder Zukunftsmusik? In Recycling und Rohstoffe; Thomé-Kozmiensky, K.J., Goldmann, D., Eds.; TK-Verlag Karl Thomé-Kozmiensky: Neuruppin, Germany, 2015; pp. 174-181.

65. Blume, T.; Walther, M. The End-of-life Vehicle Ordinance in the German Automotive Industry-Corporate Sense Making Illustrated. J. Clean. Prod. 2013, 56, 29-38.

66. Gradin, K.T.; Luttropp, C.; Björklund, A. Investigating improved vehicle dismantling and fragmentation technology. J. Clean. Prod. 2013, 54, 23-29.

67. Kwade, A.; Bärwald, G. Recycling von Lithium-Ionen-Batterien; Final Report: Braunschweig, Germany, 2012. Available online: http://www.erneuerbar-mobil.de/de/projekte/ foerderprojekte-aus-dem-konjunkturpaket-ii-2009-2011/batterierecycling/abschlussberichterecycling/abschlussbericht-lithorec.pdf (accessed on 16 September 2015).

68. Hörnig, G. Recycling von NdFeB-Magneten aus elektrischen Antrieben-Das Projekt MORE. In Recycling und Rohstoffe; Thomé-Kozmiensky, K.J., Goldmann, D., Eds.; TK-Verlag Karl Thomé-Kozmiensky: Neuruppin, Germany, 2015.

69. Tytgat, J.; Treffer, F. Recycling of Li-ion and NiMH batteries from electric vehicles: Technology and impact on life cycle. In Proceeding of the Belgian Platform on Electrical Vehicles, Brussels, Belgium, 31 March 2011.

70. Friedrich, B. Rückgewinnung der Wertstoffe aus zukünftigen Li-Ion-basierten Automobil-Batterien: Lithium-Ionen-Batterie (LIB2015). Final Report, 2012. Available online: http:/edok01.tib. uni-hannover.de/edoks/e01fb13/769010806.pdf (accessed on 16 September 2015).

71. Vezzini, A. Manufacturers, Materials and Recycling Technologies. In Lithium-Ion Batteries; Elsevier: Oxford, UK, 2014; pp. 529-551.

72. Tytgat, J. Li-Ion and NiMH Battery Recycling at Umicore: Strategic Choices. ERTRAC Expert Workshop, Brussels, 19 June 2009. Available online: http://www.smart-systems-integration.org/ public/electric-vehicle/battery-workshop-documents/presentations/Jan\%20Tytgat\%20Umicore.pdf/ at_download/file (accessed on 9 July 2015).

73. Elwert, T.; Goldmann, D.; Schirmer, T.; Strauß, K. Recycling of lithium ion traction batteries: The LiBRi project. In Proceedings of the European Mineral Resources Conference, Leoben, Austria, 19-21 September 2012; pp. 575-603.

74. Schmid, D.; Zur-Lage, L. Perspektiven für das Recycling von AltfahrzeugenModerne Fahrzeuge und angepasste Recyclingverfahren. In Recycling und Rohstoffe, Band 7; Thomé- Kozmiensky, K.J., Goldmann, D., Eds.; TK-Vlg: Neuruppin, Germany, 2014.

75. Hanisch, C. Recycling of Lithium-Ion. Batteries; Lion-Engineering, June 14, 2014. Available online: http://www.lion-eng.de/images/pdf/Recycling-of-Lithium-Ion-BatteriesLionEngineering.pdf\%20 (accessed on 16 September 2015). 
76. Hoyer, C. Strategische Planung des Recyclings von Lithium-Ionen-Batterien aus Elektrofahrzeugen in Deutschland; Springer Fachmedien Wiesbaden: Wiesbaden, Germany, 2015.

77. Hanisch, C.; Haselrieder, W.; Kwade, A. Verfahren zum Wiedergewinnen von Aktivmaterial aus Einer Galvanischen Zelle und Aktivmaterial-Separationsanlage, Insbesondere Aktivmetall-Separationsanlage. Available online: https://data.epo.org/publication-server/rest/ v1.0/publication-dates/20150930/patents/EP2742559NWB1/document.pdf (accessed on 16 September 2015).

78. Grützke, M.; Mönnighoff, X.; Horsthemke, F.; Kraft, V.; Winter, M.; Nowak, S. Extraction of lithium-ion battery electrolytes with liquid and supercritical carbon dioxide and additional solvents. RSC Adv. 2015, 5, 43209-43217.

79. Jäckel, H.-G.; Wuschke, L.; Peuker, U.A. Probleme der Aufbereitung metallhaltiger Werkstoffverbunde aus lithiumhaltigen Geräten und Batterien. Chem. Ing. Tech. 2014, 86, 806-813.

80. Buchert, M.; Jenseits, W.; Merz, C.; Schüler, D. Ökobilanz zum, Recycling von Lithium-Ionen-Batterien (LithoRec); Final Report: Darmstadt, 2011. Available online: http://www.erneuerbar-mobil.de/de/projekte/foerderprojekte-aus-dem-konjunkturpaket-ii-2009-2011/ batterierecycling/abschlussberichte-recycling/lca-analyse-lithorec.pdf (accessed on 16 September 2015).

81. Walachowicz, F.; March, A.; Fiedler, S.; Buchert, M.; Sutter, J.; Merz, C. Recycling von Elektromotoren-MORE: Ökobilanz der Recyclingverfahren; Final Report: Darmstadt, Germany, 2014. Available online: http://de.slideshare.net/AndrewMarch/morelcaendberichtfinal17okt2014 (accessed on 16 September 2015).

82. Klier, T.; Risch, F.; Franke, J. Disassembly strategies for recovering valuable magnet material of electric drives. In Proceedings of the 2013 3rd International Electric Drives Production Conference (EDPC), Nürnberg, Germany, 29-30 October 2013; pp. 1-3.

83. Klier, T.; Risch, F.; Franke, J. Disassembly, recycling, and reuse of magnet material of electric drives. In Proceedings of the 2013 IEEE International Symposium on Assembly and Manufacturing (ISAM), Xi'an, China, 30 July 30-2 August 2013; pp. 88-90.

84. MORE Consortium. "MORE"-A Project on Recycling of Components and Strategic Metals of Electric Drive Motors; Final Presentation of the Research Project; MORE Consortium: München, Germany, 2015.

85. Graedel, T.E.; Allwood, J.; Birat, J.-P.; Buchert, M.; Hagelüken, C.; Reck, B.K.; Sibley, S.F.; Sonnemann, G. Recycling Rates of Metals; United Nations Environment Programme: Nairobi, Kenya, 2011.

86. Binnemans, K.; Jones, P.T.; Blanpain, B.; van Gerven, T.; Yang, Y.; Walton, A.; Buchert, M. Recycling of rare earths: A critical review. J. Clean. Prod. 2013, 51, 1-22.

87. Elwert, T.; Goldmann, D.; Schmidt, F.; Stollmaier, R. Hydrometallurgical recycling of sintered $\mathrm{NdFeB}$ magnets. World Metall. 2013, 66, 209-219.

88. Elwert, T.; Goldmann, D.; Römer, F. Separation of lanthanides from NdFeB magnets on a mixer-settler plant with PC-88A. World Metall. 2014, 67, 287-296.

89. Elwert, T. Entwicklung eines hydrometallurgischen Recyclingverfahrens für NdFeB-Magnete. Papierflieger: Clausthal-Zellerfeld, Germany, 2015. 
90. Van Schaik, A.; Reuter, M.A. Material-Centric (Aluminum and Copper) and Product-Centric (Cars, WEEE, TV, Lamps, Batteries, Catalysts) Recycling and DfR Rules. In Handbook of Recycling: State-of-the-Art for Practitioners, Analysts, and Scientists; Worrell, E., Reuter, M., Eds.; Elsevier: Waltham, UK, 2014; pp. 307-378.

(C) 2015 by the authors; licensee MDPI, Basel, Switzerland. This article is an open access article distributed under the terms and conditions of the Creative Commons Attribution license (http://creativecommons.org/licenses/by/4.0/). 